\title{
YARGI KARARLARININ GEREKÇELİ OLMASI ÜZERİNE BİR DEĞERLENDİRME
}

AN EVALUATION ABOUT THE JUSTIFICATION OF JUDICIAL DECISIONS

Hakemli Makale

Hilal ALBAL ULAŞ*

\section{IÇCiNDEKILER}

GİRİS

1244

I. GEREKÇE KAVRAMI.

1247

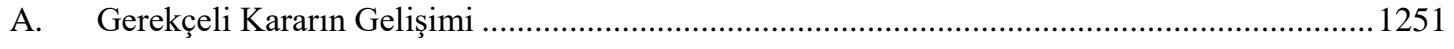

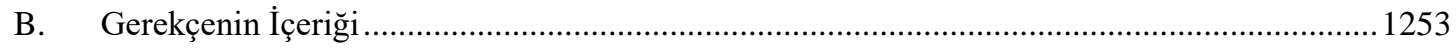

1. Delillere ve Taleplere İlişkin Gerekçelerin İçeriği ......................................................... 1254

2. İleri Sürülen İddia ve Savunmalara İlişkin Gerekçelerin İçeriği ....................................... 1255

3. Hukukî Yorumun Gerekçede Belirtilmesi ........................................................................... 1257

II. YARGI KARARLARINDA GEREKÇE........................................................................ 1260

A. Kısa Karar- Gerekçeli Karar Ayrımında Gerekçe ............................................................. 1261

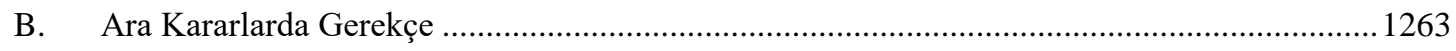

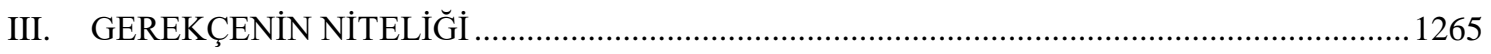

IV. ADİL YARGILANMA HAKKI VE GEREKÇELİ KARAR ................................................. 1270

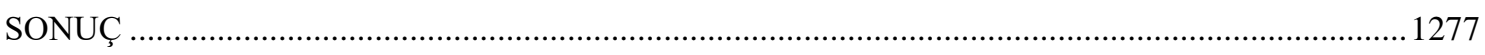

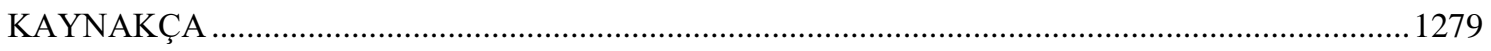

DOI: $10.32957 /$ hacettepehdf.958575

Makalenin Geliş Tarihi: 29.06.2021

Makalenin Kabul Tarihi: 19.10 .2021

* Araştırma Görevlisi, İnönü Üniversitesi Hukuk Fakültesi İdare Hukuku Anabilim Dalı. E-posta: hilal.albal@inonu.edu.tr.

ORCID: 0000-0002-1645-2154.

$\mathrm{Bu}$ makalede, Hacettepe Üniversitesi Hukuk Fakültesi Dergisi Araştırma ve Yayın Etiği ilkelerine uyulmuştur. 


\title{
ÖZ
}

Yargı kararları, sadece somut uyuşmazlığı çözmekle kalmaz aynı zamanda uyuşmazlı̆̆ın konusu ile ilgili genel ilke ve kurallar koyar. Yasal düzenlemelere göre, yargı kararının gerekçeli olması zorunludur. Ancak gerekçenin içeriği konusunda, mevzuatta bir açıklık bulunmamaktadır. Bu konu, doktrin ve uygulama açısından cevap aranmaya çalışılan bir sorun hâline gelmiştir. Özellikle, Avrupa İnsan Hakları Mahkemesi (AİHM)'nin ve Anayasa Mahkemesi (AYM)'nin "gerekçeli karar hakkı" nın ihlali konusunda verdiği kararlar konuyu daha da önemli hale getirmiştir. Zira "gerekçeli karar hakkı" Avrupa İnsan Hakları Sözleşmesi (AİHS)'nin 6'ncı maddesi ve Anayasa'nın 36'ncı maddesinde yer alan adil yargılanma hakkının somutlaşmış hali olarak görülmektedir. Ulusal ve uluslararası düzeyde önem atfedilen gerekçenin tanımı ve içeriği belirsizliğini korumaktadır. Bu çalışmanın amacı, gerekçenin içeriği konusunda farklı görüşleri inceledikten sonra adil yargılanma ilkesi ile ilişkisini değerlendirmektir.

Anahtar Kelimeler: Yargı kararı, gerekçe, gerekçeli karar hakkı, adil yargılanma hakkı.

\begin{abstract}
Judical decisions not only resolve the concrete dispute, but also lay down general principles and rules on the subject of the dispute. According to regulations, the judicial decision must be justified. However, there is no clarity in the legislation on the content of the justification. This issue has become a problem in terms of doctrine and practice. In particular, the decisions of the European Court of Human Rights (ECHR) and the Constitutional Court on the violation of the right of justified decision made the issue even more important. The right to a fair trial under Article 6 of the European Convention on Human Rights (ECHR) and Article 36 of the Constitution includes the right to a reasoned decision. The definition and content of the justification attributed to national and international level remains unclear. The aim of this study is to critically discuss different views on the content of the rationale and to make a review on this subject.
\end{abstract}

Keywords: Judical decision, justification, reason, the right of justified decision, the right to a fair trial.

\section{GíRiş}

Yarg1 yetkisi karar vermek suretiyle kullanılır. Mahkemenin verdiği her karar, prensip olarak, onun önüne gelen somut uyuşmazlık hakkında "Anayasa, kanunlar ve hukuk" çerçevesinde vicdani kanaatini ifade eder. Bu vicdani kanaatin, söz konusu 
çerçeveye uygunluğu ise kararın gerekçesiyle ortaya konur ${ }^{1}$. Yargı kararlarının gerekçeli olması, hem davanın taraflarına kararın nedenini açıklaması, hem de yargı denetimini kolaylaştırması ve kararları etkili kılması yönlerinden zorunludur² ${ }^{2}$ Kararların açık bir ifade ile gerekçelendirilmesi, kararın yasama veya idari düzenlemeler ile müdahale edilmesini de engelleyecektir.

1982 Anayasası'nın 9'uncu maddesine göre, yargı yetkisi, Türk Milleti adına bağımsız ve tarafsız mahkemelerce kullanılır. 141'inci maddenin 3'üncü fikrasına göre, bütün mahkemelerin her türlü kararları gerekçeli olarak yazılır. Benzer bir düzenleme Anayasa'nın 125'inci maddesinin 5'inci fikrasında da karşımıza çıkmaktadır. Düzenlemeye göre, yürütmeyi durdurma kararları gerekçeli olarak verilmelidir. Görüldüğü üzere, uyuşmazlıkları kesin olarak çözme faaliyeti olarak tanımlanan ve yargılama işlevinin somutlaşmış hali olan yargı kararlarının gerekçeli olmaları anayasal bir zorunluluktur. Bununla birlikte, yargı kararlarının, tatmin edici gerekçelerle yazılması, aynı zamanda adil yargılanma hakkının gereğidir. Gerekçe zorunluluğu, yargılamayı yapan mahkemenin keyfi karar verme yolunu kapatarak adil yargılanmaya katkı sağlamaktadır. Bu durum yargılama faaliyetinin, şeffaflığı, hesap verilebilirliği ve aleniliği açısından önemlidir ${ }^{3}$.

Hukuk sistemimize göre, hukukî bir sorunun çözümüne yönelik karar vermek ve tarafları verilen kararın esası hakkında tatmin etmek hâkimin görevidir. Yargı kararı, sonuçları itibari ile otoriter bir kavramdır, öneri veya iknaya yönelik bir işlem değildir ${ }^{4}$. Yargı kararları, hukukî bir kavram olarak meselenin çözümü hakkında mahkemelerce verilen kararları ifade eder. Mahkeme, bir davranışın hukuka aykırı olup olmadığını, hukuka aykırı davranmış olana uygulanacak müeyyideyi, kısaca neyin hukuka uygun bulunduğunu vereceği bir hükümle, kararla, saptar. Hukuka aykırı davranışlar muhakeme

1 ATALI, Murat, Pekcanıtez Usul Medeni Usul Hukuku, 15. Basım, XII Levha Yayınları, İstanbul, 2017, Cilt III., s. 1967.

2 GÖZÜBÜYÜK, Şeref, Yönetsel Yargı, 24.Basım, Turhan Kitapevi, Ankara, 2011, s. 503.

3 ATAY, Ethem, "Yargı Kararlarının Gerekçelendirilmesi ve İdari Yargıdaki Uygulama Alanı", Danıştay Dergisi, Yı1l:2018, Sayı:147, (s. 7-32), s. 21.

4 PONTHOREAU, Marie Claire, "Réflexions sur la motivation des décisions juridictionnelles en droit administratif français”, R.D.P., Y1l: 1994, (s.747-765), s.748. 
edilerek bir hükme bağlandığı zaman hukuktan ve hukuk düzeninden söz edilebilir ${ }^{5}$. Gerekçe, mahkemenin yaptığı muhakemeyi açıkladığg, hükme nasıl vardığını belirttiği bir alan olmakla birlikte hukukî sebepleri de içeren yargı kararının bir parçasıdır. Gerekçeli karar, aynı zamanda yargı makamlarının kendilerini ifade edebilmelerinin bir yolu olarak karşımıza çıkar.

Gerekçeli yargı kararının işlevi yargı düzenlerine göre farklılık gösterebilir. Örneğin, içtihadi bir hukuk dalı olan idare hukukunda yargı kararları neredeyse “normatif” bir güce sahiptir. İçtihadilik özelliği, idari yargı düzenindeki mahkemelerin kararlarını verirken, bazen uyuşmazlığın konusu ile ilgili genel ilke ve kurallar koymalarını zorunlu hale getirmektedir. Bu ilke ve kurallar, kararın gerekçe kısmında karşımıza çıkar. İşte bu nedenle, yargı kararlarının gerekçeli olması, çalışma konusu olarak seçilmiştir. Bu çalışmada, araştırma sorumuz "yargı kararlarında tatmin edici bir gerekçe nasıl olmalıdır?" olmuştur. Esasen konunun detayına girdikçe başka alt sorularla da karşılaşılmıştır. Bunlardan biri Anayasa Mahkemesi ve AİHM'nin gerekçe ilkesine bakış açısıdır. Bu nedenle, bu husus da çalışmada incelenmiştir.

Gerekçe ile ilgili araştırılması gereken konular oldukça fazladır. Ancak bir akademik çalışmanın sınırlarının belirlenmesi gerekliliğinden mütevellit, bazı konular çalışma dışında bırakılmıştır. Gerekçelerin bağlayıcılığı, özellikle uygulamada kafa karışıklığı yaratan gerekçenin yazım şekli gibi konular kapsam dışında tutulmuştur.

$\mathrm{Bu}$ çalışma, dört ana başlıktan oluşmaktadır. Gerekçe kavramı başlı̆̆ında gerekçenin doktrin ve yargı oranları tarafından yapılmış tanımları, kavramın gelişim süreci ve içeriği incelenmiştir. Yargı kararlarında gerekçe başlığında karar türlerindeki gerekçeler ile ilgili tartışmalar üzerinde durulmuştur. Gerekçenin niteliği başlığında hükmün gerekçe kısmına yazılan her bilginin gerekçe olup olmadığı tartışılmış, hangi durumlarda nitelikli bir gerekçeden bahsedileceği anlatılmıştır. Son başlıkta ise hem Anayasa Mahkemesinin hem de Avrupa İnsan hakları Mahkemesinin, gerekçesiz kararların adil yargılanma hakkını ihlal ettiği yönündeki kararlarına istinaden gerekçeli

ARAL, Vecdi, Hukuk ve Hukuk Bilimi Üzerine, 7. Basım, On iki Levha Yayınları, İstanbul, 2012, s. 105. 
karar ile adil yargılanma hakkının ilişkisi doktrin görüşleri ve yargı kararları ile desteklenerek incelenmiştir.

\section{GEREKÇE KAVRAMI}

Herhangi bir konuda "görüş" ileri süren bir kişinin, görüşünü gerekçelendirmesi beklenir. Zira gerekçe, görüşün muhatapları tarafından kabul edilmesini kolaylaştırır. Görüşün muhatapları tarafından kabul edilmesinin beklenmemesi ya muhatapların ciddiye alınmadığı ya da eylemin "fuzuli" olduğu anlamına gelir'. Toplumsal hayatta var olan bu durum, devlet açısından da geçerlidir. Modern hukuk devletinde, devlet organları kararlarını açıklarken kararın muhataplarını ikna, kararın hukuka uygun olduğunu ispat ve kamuoyunun kararı kabul etmesi çabasını taşımalıdır. Gerekçenin hukuk devleti ile bağlantısı da bulunmaktadır. Ökçesiz'e göre kamu görevlisi devlet adına yaptığı işlemin hukuk devletine uygun olup olmadığını iyi bilmeli ve bu bilgisini de işlemin ilgililerine açık, tutarlı ve yeterli şekilde açıklayabilmelidir. Bu durum kişilerde hukuk devleti bilincini geliştirmektedir ${ }^{7}$.

Yarg1 kararlarında gerekçe, kısaca, yargıcın hükmünü dayandırdığı nedenler anlamına gelir ${ }^{8}$. Türk Dil Kurumu sözlüğe göre "mahkeme kararlarında, kararın dayandı̆̆ yasal ve hukuksal sebeplerin gösterilmesi” dir9.

Yargılama makamları, iddia ve savunma makamlarının (veya davacı ve davalının) ortaya koyduğu delillerin tartışılması ve değerlendirilmesi sonucunda, son kararlarını verirler. Yargı kararlarında meselenin, sonuçta gösterilen şekilde çözülmesinin nedenini ve niçinini gösteren kısım gerekçedir ve hüküm vermenin bir uzantısıdır ${ }^{10}$.

6 UZUN, Ertuğrul, "Yargıtay Kararlarından Örneklerle Yargı Kararlarında Gerekçelendirme Zafiyeti", Legal Medeni Usul ve İcra İflas Hukuku Dergisi, Y11:2007, Sayı: 2, (s. 359-376), s. 360.

7 ÖKÇESIZ, Hayrettin, "Devlet ve Gerekçesi”, Hukuk Felsefesi ve Sosyolojisi Arkivi (HFSA) 10, İstanbul Barosu Yayın1, Y11:2003, (s. 11-13). s.12

8 YILMAZ, Ejder, Hukuk Sözlüğü, Yetkin Yayınları, Ankara, 2006., s. 238.

9 www.tdk.gov.tr, e.t. 23.04.2018.

10 YERDELEN, Erdal, Ceza Muhakemesinde Hükmün Gerekçesi, Adalet Yayınevi, Ankara, 2015, s. 5 . 
Gerekçe doktrinde de farklı şekillerde tanımlanmıştır. Aşçıoğlu, hâkimin kanısının nedenlerini açık ve doğru anlatması nedeniyle gerekçe ile adil yargılanma düzeninin sağlanması arasında bağlantı kurmuştur. Şeker'e göre gerekçe "hukukun adalete dönüşmesi” nin bir aracıdır ${ }^{11}$. Özyörük ise gerekçeyi, yargı kararı özelinde değil, devlet tasarruflarının gerekçeli yazılmasından hareketle tanımlamaya çalışmıştır. Yazara göre, gerekçe, bir "devlet tasarrufunun" ittihazı yetkisinin hangi kanuni kaynaktan veya genel hukuk ilkesinden alındığının gösterilmesi değildir. "Bu karar (veya tasarruf), falan kanunun filan maddesi uyarınca ittihaz edilmiştir" demek "gerekçe" göstermek sayılmaz. Gerekçe, "yetkili mercii, bir kararın (veya tasarrufun) ittihazına sevk eden sebeplerin (olaylar, iddialar, ihtimaller muvacehesinde) teker teker gösterilmesi, tartışılması, hukuk düzeninin verileri karşısında, hukuk tekniği ve hukuk mantı̆̆ ile kararın yarattı̆̆ hukukî durumun (veya ihtiva ettiği hukukî emrin) hukukî isabet ve sıhhatinin ispatıdır"12. Sunay’a göre gerekçe, benzer şekilde hükmün bütün sav ve iddiaların nedenlerinin detaylıca açıklandığı kısmıdır ${ }^{13}$.

Yargıtay, kararların gerekçeli olmasını, iddiaların detaylı bir şekilde değerlendirilmesi, hükmün dayandığı maddî ve hukukî sebeplerin açıklanması, özellikle de hukuka aykırı bulunan nedenlerin belirtilmesi olarak anlamıştır ${ }^{14}$.

$\mathrm{Bu}$ açıklamalar 1şığında söylenebilir ki gerekçe, yargı kararının içermesi gereken resmi ve hukuki zorunlu verilerin ötesini içermelidir. Gerekçeli karar, hâkimi çözüme

11 ŞEKER, Hilmi, Esbabı Mucibeden Retoriğe Hukukta Gerekçe, Beta Yayınları, İstanbul, 2010, s. 14.

12 ÖZYÖRÜK, Mukbil, Tercüman Gazetesi, 07 Aralık 1979 tarihli köşe yazısı.

13 SUNAY, Zuhal Aysun, İptal Davalarında Gerekçeli Karar Hakkı, Seçkin Yayınevi, Ankara, 2016, s. 24.

14 “Uyuşmazlıkların çözümünde yargıya düşen en önemli görevlerden birisi de açık ve net çözümler bulmak, anlaşılabilir tutarlı kararlarla kamu düzen ve barışının sağlanmasına hizmet etmek olmalıdır. Hükmün açık ve net olması gereği hüküm sonucu ile sinırlı olmayıp, iddiaların tek tek ele alındiğl, cevaplandırıldı ̆̆ hukuka ve yasaya aykırı bulunma ya da bulunmama nedenlerinin açıklandı̆̆l, yasal dayanakların gösterildiği, anlamaya ve denetime elverişli gerekçenin varlığını da gerektirir. Zira taraflar ancak gerekçe sayesinde hükmün hangi maddî ve hukukî sebebe dayandırıldı̆̆ını anlayabilecekleri gibi Yargıtay denetimi de ancak kararın gerekçe içermesi halinde, mümkün olacaktır. İşte bu nedenledir ki, kararın gerekçesinde hangi maddî vakıanın hangi hukukî sebeple davacıyı haklı gösterdiğinin açıklanması halinde ancak, HUMK'un 388”'inci maddesine uygun bir kararın varlı̆̆ından söz edilebilecektir. Gerek Anayasamız, gerek 1086 Sayılı HMUK ile getirilen ve yukarıda açılanan yasal düzenlemelerin nihai amacı budur”. YHGK, T. 03.12.2003, K. 2003/776, E.2003/720, Kazanc1 Bilgi Bankası. 
götüren hukuki ve fiili nedenleri, tarafların esaslı iddialarının cevabını, hâkimin olayda uyguladığı mevzuatı yorumlamasını ve hatta seçtiği yorum metodunun nedenini içermelidir. Gerekçe, uyuşmazlığın taraflarını tatmin etmeli özellikle idari yargı düzeninde idarelerin kararı uygularken çelişkiye düşmelerini engellemelidir.

Gerekçe, "nereden biliyorsun” sorusuna cevap almamızı sağlar. Bu cevap bizi "doğru” veya "gerçek" bilgiye götürür. Buradan şöyle bir çıkarımda bulunmamız hatalı olmaz; "yanlış bilgi yanlış sonuca; doğru bilgi ise doğru sonuca götürür”. İşte usul hukukunun konusu, hukukî uyuşmazlıkların doğru bir şekilde çözülmesi için başka bir ifadeyle "doğru sonuca" ulaşmak için gerekli ortamı yaratmaktır ${ }^{15}$. Bu ise düzgün ve detaylı yazılmış bir gerekçe ile mümkündür.

Mahkemenin, tarafların iddialarına cevap vererek sonuca nasıl vardığını göstermek için izlediği yol gerekçedir. Bu bağlamda hâkimin bu yolu anlatmak ve temellendirilmek için kullandığı kelimeleri özenle seçmesi önemlidir ${ }^{16}$. Karar verme sürecinde hâkim, yasalardaki düzenleniş amacını keşfederek önündeki davaya uygulanacak hukuku saptamalı ve bu uygulamayı yaparken adil davranmalı, ciddi/belirgin nitelikte bir hata yapmamalıdır. $\mathrm{Bu}$ aşamada verilen kararın belli bir hukukî gerekçeyi de içermesi gerekmektedir. Bu şekilde hâkim, hukuk yaratmaktadır; bilimsel soyutluluğu somutlaştırmaktadır ${ }^{17}$.

Gerekçenin en önemli dayanağı mantıktır. Hukukî bir sorunun çözümünde, bütün fikirlerin gerek mantık ve sıralama gerekse üslup bakımından birbirine uyması gerekir. Hukukçunun ödevi, kanunu uygulayarak olayı kanun gözüyle ölçmektir. Mantıkta, bir iddia ancak, mantıki bir sıra ile belli bir nedenin zorunlu sonucu sayılabildiği takdirde, doğru olarak kabul edilir. Hukukta da buna benzer bir kural yürür, bir talep, hukukî bir muamele ile belli bir kuralın zaruri sonucu olarak kabul edildiği takdirde haklı sayılır. Başka bir deyişle; varılan sonucun doğruluğu, muhakemenin biçimine, tamam oluşuna,

15 Bilgi teorisi ve gerekçe üzerine daha ayrıntılı açıklama için bkz. AKIN, İbrahim, Yargı Kararlarında Gerekçe (Bilgi Teorisi ve Mantık Açısından Değerlendirme), Kazancı Bilgi Bankası, Ankara, 2001, s. $20 \mathrm{vd}$.

16 BLANCO, Florent, Contentieux Administratif, 1. Edition, Themis Droit Puf, Paris, 2019, s. 659.

17 YÜCEL, Mustafa Tören, "Kararlarda Gerekçe ve Muhalefet Şerhi”, HFSA (8. Kitap), İstanbul Barosu Yayını, Y1l: 2003, (s. 162-170), s. 163. 
doğruluğuna ve mantıki olup olmamasına bağlıdır ${ }^{18}$. Tarafların ve gerekirse üst mahkemenin ve bu kararları inceleyecek hukukçuların hâkimin keyfi hareket edip etmediği, kanun ve hakkaniyete uygun karar verip vermediği hususunda bir sonuca varabilmeleri için tek vasıta, kararın gerekçesidir. Gerekçesiz karar, isabetli olabilir, fakat kararın isabetli olup olmadığı hakkında gerekçe olmadan bir sonuca varmak mümkün değildir ${ }^{19}$.

Özetlemek gerekirse; bir yargı kararında gerekçenin varlığı mantıki bir zorunluluktur. Sadece bir karar vermek yeterli değildir, aynı zamanda kararın nedenini açık bir şekilde belirtmek gerekir ${ }^{20}$. Uyuşmazlık konusu olay ile ortaya konulan delillerden hareketle varılan sonuç olan karar arasında sebep-sonuç ilişkisi kurulmalıdır. Gerekçe aynı zamanda ahlaki bir yükümlülüktür. Çünkü hâkimin veya mahkemenin çözdügü uyuşmazlık hakkında verdiği karar ile öncelikle taraflar olmak üzere, tüm ilgililere bilgi verme ödevi bulunmaktadır ${ }^{21}$. Gerekçeler, kararların temellendirilmesini sağlar, kararlara meşruiyet kazandırır, keyfilikleri önler, “Türk Milleti” adına karar veren yargı organının kararlarının, muhataplarının tatminine hizmet eder, yargıyı içtihatlar yönünden zenginleştirir, hukuk devleti ve yargıya olan güveni arttırır ${ }^{22}$. Hukuka aykırı, haksız bir kararı makul bir gerekçeye bağlamak zordur, hatta imkânsızdır. Bu itibarla gerekçe, ayrıca mahkemeyi daha iyi düşünmeye, işi daha esaslı incelemeye sevk eder ${ }^{23}$. Gerekçe aynı zamanda hakimleri kararları verirken ve kaleme alırken titiz olmaya sevk ederek, kanun yollarında kararların incelenmesini kolaylaştıracaktır ${ }^{24}$.

18 HİRŞ, Ernst, Pratik Hukukta Metot, 8. Basım, BTHAE Yayınları, Ankara, 2017, s. 99- Bu kitabın ilk baskısı 1944 tarihinde yapılmıştır, s. 99.

19 KARAYALÇIN, Yaşar, Hukukta Öğretim-Kaynaklar-Metot-Problem Çözme, 4.Basım, BTHAE Yayınları, Ankara, 1994,- Bu kitabın ilk baskısı 1977 tarihinde yapılmıştır, s. 116-117.

20 In le Conseil D’Etat, cour regulatrice, chron.1954, Aktaran; PONTHOREAU, 1994, s. 749.

21 KARAKOÇ, Yusuf, "Yargı Kararlarının Dili ve Gerekçesi”, HFSA 16. Kitap, İstanbul Barosu Yayınları, İstanbul, Y1l: 2007, (s. 275-283), s. 279.

22 TÜRKMEN, Ali, “Türk Yargı Kararlarında Gerekçe ve Önemi”, Legal Hukuk Dergisi, Cilt:13, Sayı:154, (s. 39-60), s. 55.

23 YÜCE, Turhan Tufan, Ceza Muhakemesi Hukukunda Hukuk Devleti Esasları, Atatürk Üniversitesi Basımevi, Erzurum, 1968, s.59.

24 CHAPUS, Rene, Droit du Contentieux Administratif, 8. Edition, Montchrestien, Paris, 1999, s. 906. 


\section{A. Gerekçeli Kararın Gelişimi}

Tarihteki ilk gerekçeli karara Sümer Rahip Devletlerindeki kil tabletlerde rastlandığ 1 kabul edilse de gerekçenin gelişmesi 12. yüzyılın sonunda yazının adli uygulamalarda kullanılmasına tekabül eder. Ancak gerekçeler bu dönemde oldukça fazla ve karmaşıktır ${ }^{25}$.

Günümüzde kullanılan anlamda yargı kararlarının gerekçeli olması "Fransız İhtilali ile gelişen düşünce akımlarının etkisi ve birikiminin ürünü” olarak gösterilmektedir ${ }^{26}$. İhtilalden önce, ilk olarak Fransa'da Dragguignan Tiers Etat'nın 1788 tarihli toplu istek dilekçesinde (muhtırasında) yargı kararlarının gerekçeli olması talebinin yer aldığı görülmektedir ${ }^{27}$. Fransa'da, Devrimden sonra 16-24 Ağustos 1790 tarihli Kanununa konulan hükümle, tüm mahkemelerin kararlarını gerekçeli sunmaları kanuni bir zorunluluk haline getirilmiştir. Bu kanun, Fransa'nın devrimden sonra, “yargı sistemini değiştiren" ve yargıçların artık yasama faaliyetlerine katılmalarını da engelleyen nitelikte hükümler ihtiva eden bir kanundur. Zira Fransa'da yargı, toplumsal reformun yozlaşmış ve gerici bir düşmanı olarak algılanıyordu ${ }^{28}$. Bu bilgiler 1şı̆̆ında yargı kararlarının

25 Sümerler zamanında geçen Suskun Kadın Davası, gerekçenin ortaya konulduğu ilk dava ve hüküm olarak kabul edilmektedir. M.Ö. 1850 dolaylarında Sümer Ülkesinde bir cinayet işlendi. Üç kişi, LU İnanna isimli bir tapınak görevlisini öldürdüler. Katiller, belirtilmeyen bir nedenle, kurbanın Nin-dada adındaki karısına kocasının öldürüldüğünü haber verirler. Garip bir şekilde kadın onların sırrını saklar ve yetkililere bildirmez. Ama o zaman bile, en azından uygar Sümer yurdunda adaletin eli kolu uzun ve kesindi. Cinayet Kral Ur-Ninurta'ya başkenti İsin'de bildirildi ve o da davayı Nippur'daki mahkeme işlevi göre Yurttaşlar Meclisi'nin önüne çıkardı. Mecliste bulunanların dokuzu, yalnızca üç katilin değil, kadının da cezalandırılması gerektiğini savunmuştur. Kadının, cinayeti öğrendikten sonra suskunluğunu koruduğu için suç ortağı olduğunu düşünmüşlerdir. Bunun üzerine meclisin iki üyesi kadının lehinde görüş bildirerek kadının susmasını ikrar olarak kabul etmezler. Onun cinayette yer almadığını (o gün orada olmadığını) ve bu nedenle de cezalandırılmaması gerektiğini öne sürerler. Mahkeme üyeleri savunmanın görüşüne katılır. Kadının, kocası sağ iken kadının ihtiyaçlarını karşılamaması nedeniyle cinayeti kimseye söylemediğini ve bu nedenle cinayete ortak sayılamayacăğ gerekçe olarak ortaya koymuştur." Gerçek katillerin cezalandırılmasına" karar verilerek dava sonuçlandırılır. Bu hükümde, Nippur Meclisi tarafindan sadece üç kişiye ölüm cezası verilmiştir. Bu hüküm, kararı verecek olan meclis üyelerinin bir kısmının farklı görüşte olmaları halinde, karşı oyların da gerekçesinin olacağını ortaya koymaktadır. Delillerin tartışılması ve bazı delillerin çürütülmesi de bu davada gerçekleştirilmiştir. YERDELEN, 2015, s. 90.

26 AŞÇıIOĞLU, Çetin, "Yargıda Gerekçe Sorunu", Hukuk Felsefesi ve Sosyolojisi Arkivi (8'inci Kitap), İstanbul Barosu Yayınları, İstanbul, Y11:2003, (s.154-161), s.155.

27 SELÇUK, Sami, Beccaria”nın İnsanlığa Bildirisi, İmge Yayınevi, Ankara, 2004, s.73’ten Aktaran; SUNAY, 2016, s. 22.

28 COHEN, Matilda, "Reason Giving in Court Practice: Decision - Makers At The Crossroads", Colombia Journal of European Law, Yı1: 2008, Vol:14, No:2, (s.257-276). s. 261. 
gerekçelendirilmesi zorunluluğunun, bir nevi yargı erkine güvenin az olmasından, yarg1 erkini- özellikle de Fransa'da idari yargının doğuşunun idareyi güçlendirme amacı ile kurulduğunu düşünürsek- egemenin aracı olmaktan kurtarmak amacıyla ortaya çıktığ sonucunu çıkarabiliriz. Gerçekten söz konusu düzenlemeler ile Eski Rejimin uygulamalarıyla ilişkinin koparılarak yargı kararlarının gerekçelendirilmesi, hâkimin keyfî veya taraflı karar vermesini engellemiştir ${ }^{29}$. Keza, Fransa'da İhtilalden hemen sonra, sert kuvvetler ayrılığı ilkesinin devletin bütün organlarında hissedilmesinin etkisi de yadsinamaz ${ }^{30}$.

Gerekçe kavramında bir belirsizlik vardır. Bir yandan ciddi ve ayrıntılı bir yazma sürecidir, diğer yandan da bir kontrol aracıdır. Bu iki gerekçe kavramı, iki adalet anlayışına tekabül eder. Biri tarafların müzakerelerinden adaleti bulma görevini yargıca verir, diğeri ise yasayı uygulamaktan ibarettir ${ }^{31}$. Türkiye ve Fransa'nın dahil olduğu Kıta Avrupası Hukuk Sisteminde ikinci konsept uygulanmaktadır. Ancak gerekçe yazımını sadece kanunların uygulanması olarak indirgememek gerekir. Bazen hâkim kanısının hukuka uygun olduğunu değil, yaptığı tercihin isabetli olduğunu kanıtlamak için de gerekçeyi kullanabilir.

Hâkimin kanunun denetimine tabi olmadığı Anglo Sakson Sistemlerinde gerekçe yazma yükümlülüğü bulunmamaktadır. Ancak, bu kural, iki şekilde sınırlandırılmaktadır. Bunlardan ilki; yasama organının yargı kararlarının ve idarenin işlemlerinin gerekçeli olmasını yasal bir zorunluluk olarak kabul etmesidir. İkincisi ise; öğretide çoğu akademisyen yasal bir gerekçe belirtme zorunluluğu olmadiğı konusunda hemfikir olsa da gelenek olarak hâkimlerden karara etkili olan nedenleri göstermelerini beklemektedirler. Çünkü gerekçe, şeffaflığı ve hesap verilebilirliği sağlayan, keyfi karar alınmasını önleyen hukukî bir kurumdur ${ }^{32}$. Gerekçe belirtme konusundaki serbestinin bir

29 ATAY, 2018, s. 26.

30 Fransa'da İhtilali’nden sonraki devlet yapısının detaylı açıklaması için bakınız. ÖZTÜRK, Burak, Fransız ve Türk Hukukunda İdarenin Düzenleme Yetkisinin Kapsamı, Yetkin Kitapevi, Ankara, 2009 , s. 5 vd.

31 CASTAING-ZENATI, Frédéric, "La motivation des décisions de justice et les sources du droit", Recueil Dalloz, Y1l:2007, s. 1553.

32 COHEN, 2008, s. 261-262. 
diğer istisnası ise yabancılar ile ilgili verilen kararlardır. Anglo Sakson Hukuku'nda gerekçe, Fransız ve Türk Hukuku'ndan farklı olarak; kısa, itiraz kabul etmeyen önerilerin açıklanması gibi kendini göstermektedir ${ }^{33}$.

Açıklamalar 1şığında anlaşıldığı üzere bazı hukuk düzenlerinde kararların gerekçeli olması zorunlu değildir. Yargı organlarının kararlarını gerekçeli yazmalarının zorunlu olduğu hukuk düzenlerinde, hâkimi o kararı vermeye iten her nedenin hükmün gerekçe kısmında gösterilmesi zorunlu mudur? ya da hangi hususların atlanması kararı gerekçesiz kılacaktır? Bu konular gerekçenin içeriği kısmında açıklanmaya çalışılmıştır.

\section{B. Gerekçenin İçeriği}

Gerekçenin içeriğinin tatmin edici ve tutarlı olması, hukukî dinlenilme hakkının ve adil yargılanma hakkının sağlanması açısından çok önemlidir ${ }^{34}$. Gerekçeli karar $^{35}$, mahkemenin tarafsızlığını ortaya koyan yargısal bir metin olması itibariyle de taraflar ve toplum nezdinde prestij kazanmaktadır. Gerçekten, dosya içeriğine, akla ve hukuka uygun düşen bir gerekçe sayesinde taraflar davayı hangi maddî ve hukukî sebeplerden ötürü kaybettiklerini veya kazandıklarını öğrenme ve tatmin olma şansına sahip olacaklardır. Taraflar açısından bu ihtiyacın giderilmesi temel bir insan hakkı, mahkeme açısından ise bir yükümlülüktür ${ }^{36}$. Gerekçeli karar, kişilerin adil bir şekilde yargılanmalarını sağlamayı ve kişileri denetlemeyi amaçlamaktadır. Ayrıca, tarafların muhakeme sırasında ileri sürdükleri iddialarının kurallara uygun biçimde incelenip incelenmediğini ve kendi adlarına verilen yargı kararlarının sebeplerini öğrenmelerini

33 ATAY, 2018, s. 28. Anglo Sakson hukuk sistemlerinde yargı kararlarının gerekçeli olması ve gelişimi konusunda ayrıntılı bilgi için bkz. SHUMAN, Samuel: "Justification of judicial decisions", California Law Review, Y1l: 1971, Vol. 59, No: 3, A Tribute to Hans Kelsen, (pp. 715- 732).

34 ATALI, 2017, s. 1984-1985.

35 George Vedel'e göre “iyi bir karar, davacının taraflı fakat sağlam anlatılmış maceraları ile başlar. Öyküden bahsedildikten sonra düşüncelere sıra gelir. Davacı ne istemektedir? Nelere dayanmaktadır? Elindeki argümanlar nelerdir? Danıştay bu konuda nasıl karar vermiştir? Ne zaman? Bilhassa niçin? Daha sonra en eğlenceli ana sıra gelir: kararın analizi. Kararı dikkatlice okumak, gerçekleri ve temel probleme uygulanacak prosedürleri anlamamızı engelleyen yabancı cisimleri ayırarak, karara götüren düşünceleri ayıklamak, yeniden okumak, örtük anlamları bulmaya çalışmak ve bazen de sessizliği dinlemek gerekir! Danıştay’ın kısa ve öz gerekçesi yorumcularına ve izleyicilerine gizemini açarak bu hassas zevke katkida bulunur", PONTHOREAU, 1994, s.747-748

36 TUTUMLU, Mehmet Akif, Hukuk Yargılamasında Hüküm ve Gerekçeli Karar, Seçkin Yayınevi, Ankara, 2007, s. 67. 
sağlamaktadır ${ }^{37}$. Hükmün gerekçesinde temel kararlar (örneğin idari işlemin iptali veya tazminat miktarının belirlenmesi gibi) bulunacağı gibi, tarafların ikrarı, iddia ve açıklamaları gibi tali nitelikteki hususlar da bulunur ${ }^{38}$. Yargıtay da bir kararında, kararların gerekçeli olmamasının kamu düzeni ile ilgili olduğuna işaret ederek gerekçesiz kararları bozmuştur. ${ }^{39}$.

\section{Delillere ve Taleplere İlişkin Gerekçelerin İçeriği}

Gerekçede ilk tartışılması gereken taraflarca sunulan delillerdir. Hâkim, taraflarca gösterilen veya resen toplanan delilleri ayrı ayrı ele alarak değerlendirmeli, tartışmalı; kabul ve ret sebeplerini açıklamalıdır. "Toplanan delillere göre" gibi bir ifade ile kurulan hüküm gerekçe ilkesi ile uyumlu değildir. Kararda, hükme dayanak yapılan çekişmeli vakaların aydınlatılmasına yetecek ölçüde delilin irdelenmiş ve sabit sayılan bu vakalar ile hüküm (sonuç) arasında zorunlu mantıki bağın gösterilmiş olması yeterlidir ${ }^{40}$. Nitekim, AİHM de bir kararında benzer bir görüşe yer vermiştir: "Mahkeme kararlarının gerekçeli olması adil yargılanma hakkının unsurlarından birisi olmakla beraber, bu hak yargılamada ileri sürülen her türlü iddia ve savunmaya ayrıntılı şekilde yanıt verilmesi şeklinde anlaşılamaz. Bu nedenle, gerekçe gösterme zorunluluğunun kapsamı kararın niteliğine göre değişebilir. Bununla birlikte başvurucunun ayrı ve açık bir yanıt verilmesini gerektiren usul veya esasa dair iddialarının cevapsız bırakılmış olması bir hak ihlaline neden olacaktır. ${ }^{41}$ ".

37 AYM, Sencer Başat ve diğerleri başvurusu, T. 18.6.2014, Başvuru Numarası: 2013/7800, §31,34.

38 BLANCO, 2019, s. 660.

39 Yargitay’a göre; “...Hukukun üstün kılınması, yargıya güven duyulup bunun kuvvetlendirilmesi yansız ve aleni yargılama yanında, yoğun bir mesainin ürünü olan nihai kararların da yargılama safahatına uygun, doyurucu ve inandırıcı biçimde kaleme alınmasıyla olanaklıdır. Devletin temel esaslarını düzenleyen Anayasa'da konuya yer verilmiş olması da bundandır. Varlı̆̆ından söz edilebilmesi için gerekçenin yargılama safahatına uygun olmasi gerekir. Aksi halde karar "görünürde gerekçeli" olur ki, bu da gerekçesiz karar sayılır. Kararların gerekçeli olması kamu düzenine ilişkin olmakla aksi hal bozma nedenidir". Yargitay 15. HD T. 8.03.2000 E.2 000 /829 K. 2000/1121, Kazanc1 Bilgi Bankas1.

40 TUTUMLU, 2007, s. 67

41 Bkz.Ruiz-Torija/İspanya, T. 09.12.1994, Başvuru Numarası: 18390/91, \$29-30 www.hudoc.echr.coe.int e.t.: 12.05.2018. 
Resen araştırma ilkesinin bulunmadığı yargılama düzenlerinde hâkim, aynı zamanda ispat yükünün hangi tarafa ait olduğunu doğru belirlemeli, ispat yükü kendisine düşen tarafın ispatlanmamış iddia veya savunmasını kararına dayanak almamalıdır. Hâkim/mahkeme, ancak böyle davranarak, objektif sonuçlara ulaşabilir ve davanın taraflarına güven verebilir ${ }^{42}$.

Mahkeme kararlarının gerekçelerinde, karar verilirken bir delil başka bir delile üstün tutulmuş ise bunun da gerekçede açıklanması gerekmektedir. Sonuç olarak, gerekçede hâkim, tarafların iddia, savunma, itiraz ve taleplerini değerlendirmeli, bunların kabule şayan görülme veya görülmeme sebeplerini açıklamalıdır. Burada her iddianın değil, davanın sonucu ile doğrudan ilgili ve sonucu belirleyici savların kararın gerekçesinde cevaplanmış olması halinde gerekçelendirme yükümlülüğü yerine getirilmiş demektir ${ }^{43}$.

\section{2. İleri Sürülen İddia ve Savunmalara İlişkin Gerekçelerin İçeriği}

Yargının mümkün olan hız ve tasarrufla işlemesi gereği, karara etkisi olmayan hususlar gerekçe kapsamı dışında bırakılabilirler. İleri sürülen her türlü iddiaya gerekçede ayrıntılı olarak yer verilmesi beklenmemelidir ${ }^{44}$. Anayasa Mahkemesi, bir iddianın gerekçede yanıt verilebilmesi için onun "esaslı" bir iddia olması gerektiğini belirtir. Karara göre ${ }^{45}$; "Mahkeme kararlarının gerekçeli olması adil yargılanma hakkının unsurlarından birisi olmakla beraber, bu hak yargllamada ileri sürülen her türlü iddia ve savunmaya ayrıntıll şekilde yanıt verilmesi şeklinde anlaşılamaz. Bu nedenle, gerekçe gösterme zorunluluğunun kapsamı kararın niteliğine göre değişebilir. Bununla birlikte başvurucunun ayrı ve açık bir yanıt verilmesini gerektiren usul veya esasa dair iddialarının cevapsız bırakılmış olması bir hak ihlaline neden olacaktır. İlk derece mahkemesinin başvurucunun esaslı bir iddiasını kararında tartışmamış olması nedeniyle

42 CANDAN, Turgut, Açıklamalı İdari Yargılama Usul Kanunu, 2. Basım, Maliye ve Hukuk Yayınları, Ankara, 2006, s. 617.

43 TUTUMLU, 2007, s.70

44 ALP, Mustafa, “Anayasa Hukuku Açısından Mahkeme Kararlarında Sözde (Görünürde) Gerekçe”, Prof. Dr. Mahmut Tevfik Birsel'e Armağan, İzmir; Dokuz Eylül Üniversitesi Yayını, (s. 425-441), s. 440

45 AYM, Aziz Turhan Başvurusu, Başvuru no: 2012/1269, Karar T. 08.05.2014. 
gerekçeli karar hakkının ihlal edildiğine hükmetmiştir. O halde, gerekçede tarafların iddia ve savunmalarında bulunan her hususa değinilmiş olması beklenilmemekle birlikte karara etki edecek nitelikteki iddia ve savunmaların tartışılması gerekmektedir. Örneğin, idare mahkemelerinin idareyi tazminat ödemeye mahkûm etmesi durumunda idareye isnat edilen kusurun, bu kusurun neden karara etki ettiğinin ve kararın hukukî dayanaklarının gerekçede mutlaka belirtilmesi gerekir ${ }^{46}$. Başka bir ifade ile, idarenin sorumluluğuna hükmedilen bir yargılama sonunda verilen kararın gerekçesinde, olay kısaca açıklanmalı, olaya neden olan idarenin davranışı, ortaya çıkan zarar ve aralarında kurulan illiyet bağı belirtilmelidir. Bunların yanında eğer bilirkişi incelemesi yapıldı ise bilirkişi raporlarına da kısaca yer verilmelidir. Bütün bunlara dikkat edildiğinde uyuşmazlığın karara bağlanma süresine, tarafların sayısına, bilirkişi raporu istenme sıklığı gibi verilerle değişiklik gösterse bile ortalama 3 veya 4 sayfalık bir gerekçeli kararın ortaya çıkması beklenmektedir.

İddia ve savunmaların gerekçede yanıt verilmesi hususunda Fransa idarî yargı düzeninde kullanılan sistem ülkemizde de kabul edilebilir. Buna göre, usul ekonomisi kuralı gereğince, iddia ve savunmalara verilen cevapların gerekçede yer alması konusunda; kabul edilen ve reddedilen iddialar ile ilgili olarak farklı tutuma gidilmektedir. İddiaların kabulü halinde, örneğin idari işlemin iptal edilmesi durumunda, hâkimin bu sonucu destekleyen bütün iddialara cevap vermesi, usul ekonomisi gereğince beklenmemektedir. Bu kurala göre, eğer davacının iki tane iddiası varsa bu iddialardan karara etkisi açısından en özeli ve önceliklisi seçilip gerekçeye o yazılmalıdır. Yargıcın iki tanesini de gerekçeye alma zorunluluğu bulunmamaktadır. Bu durum, yargının işini kolaylaştıracak, hâkimin daha az çaba sarf etmesini sağlayacaktır ${ }^{47}$.

Usul ekonomisi, yargının işini kolaylaştırmakla birlikte, bazı iddiaların cevapsız kalması ve iddia sahibinin yargılamadan tatmin olamaması gibi sonuçlar doğurabilir. Taraflar ikincil de olsa yargılamaya etki eden hususlar konusunda kısmi bir görüşe sahip olurlar. Örneğin, idare, gerekçede belirtilen hukuka aykırılığı düzeltme imkânına sahip

46 BROYELlE, Camille, Contentieux Administratif, 7. Edition, L.G.D.J., Paris, 2019, s.267.

47 Gerekçeye geçirilmeyen "diğer iddiaların incelenmesine gerek duyulmadığı" gerekçede belirtilmelidir. BROYELLE, 2019, s. 268. 
olabilecekken belirtilmeyen hususları tekrarlayabilecektir. Bunu önlemek için hâkim, bazen vardığı sonuçları destekleyen bütün iddialara cevap verebilir. Böylece taraflar, iddialarının hepsi hakkında bilgilendirilirler ${ }^{48}$. Bilindiği üzere idari yargıda bir iptal davasında, idari işlemin iptalini gerektirecek her türlü hususa gerekçede yer verilmesi beklenemez ancak idari işlemin iptal nedenleri hakkında gerekçe üzerinden idareye detaylı bilgi verilmesi aynı hataların tekrar yapılmasını engelleyebilecek midir? $\mathrm{Bu}$ soruya olumlu yanıt verilmesi uyuşmazlıkları azaltacağı için yargının daha hızlı çalışmasını sağlayacaktır ${ }^{49}$.

İddiaların reddi halinde ise, iddiası reddedilen taraf için gerekçede ret sebeplerine ilişkin şüphe bırakmayacak şekilde, tatmin edici cevaplar bulunmalıdır. Bunun iki istisnası bulunmaktadır; istisnalardan ilki reddedilen iddianın davanın sonucuna etki etmemesidir. Diğeri ise, davanın esasa girilmeden, usulden reddedilmesidir. Örneğin, hâkim, ret veya yasaklılık durumları nedeniyle davadan el çektiğinde, taraflar, iddialarına cevap vermeden ayrilmaya yetkilidir ${ }^{50}$.

\section{Hukukî Yorumun Gerekçede Belirtilmesi}

Yargılama, somut olayın sınırlarının tüm yönleriyle belirlenmesi, soyut hukuk kuralının tekniğine uygun olarak yorumlanıp somut olaya uygulanması demektir. Medeni Usul Hukukunda altlama faaliyeti olarak adlandırılan bu durum hâkim tarafından doğru yapılmalı ve gerekçeye belirsizliğe neden olmayacak şekilde işlenmelidir. Altlama faaliyetini "tarafların getirdiği ve ispat ettiği dava malzemesi ile hâkimin tespit edip bulduğu hukuk normunun soyut unsurlarının karşılanıp karşılanmadığının tespitine yönelen bir yargısal faaliyet" olarak tanımlamak mümkündür ${ }^{51}$. Altlama faaliyetinde yanlış değerlendirme yapılması kanun yolunda bozma sebebidir ${ }^{52}$.

48 BROYELLE, 2019, s. 269.

49 PONTHOREAU, 1994, s. 759.

50 BROYELLE, 2019, s. 270.

51 YAVAŞ, Murat, "Medeni Yargılamanın Amacı Bağlamında İspat Yükü Kavramı”, Mehmet Akif AYDIN'a Armağan, Marmara Üniversitesi Hukuk Fakültesi Dergisi, Y11:2015, (s.741-761), s. 747.

52 PEKCANITEZ, Pekcanıtez Usul, 2019, s. 2212-2213. 
Yarg1 organı, kararını tüm yönleriyle ortaya koyacak biçim ve üslupta kaleme almalıdır. Başka bir deyişle, maddî olayı anlatıp, ilgili hukuk kuralını yazarak, bu duruma göre işlemin hukuka uygun olduğunu ya da olmadığını söylemek, gerekçe değildir. Bir karara gerekçeli denilebilmesi için, kararda, tarafların dayandığı maddî ve hukukî sebebin gerçeğe ve hukuka uygunluğu çeşitli yönleriyle ve tarafların iddia, talep ve savunmaları da karşılanmak suretiyle ortaya konulmalıdır. Örneğin, davanın konusu bir idari işlem veya eylemse idarenin uyguladığı (yasal veya idarî) düzenlemenin hukuka uygunluğu, uyuşmazlığa uygun yorum teknikleri kullanılarak tespit edilmeli; yapılan tespit ve yoruma göre sonuca ulaşılmalıdır ${ }^{53}$. O halde örnek bir gerekçeli kararda sebebin gösterilmesi gerekir. Nitekim Danıştay da bir kararında hukukî sebebin gösterilmemesinin, ilk derece mahkemesinin kararını hukuka aykırı hale getirdiğini belirtmektedir. Karara göre; “... dava konusu vergi tarhına esas matrahın 16.750.000lira olması; ayrıca, olaya, kaçakçılık cezası değil ă̆ır kusur cezası uygulanması gerektiği sonucuna varılmış ise de mahkemeyi bu yargıya götüren maddî ve hukukî nedenler hakkında herhangi bir açıklama yapılmamıştır. Başka anlatımla; kararda gerekçe gösterilmemiştir..."

Hirş yorumu, genel ve soyut ifadeler kullanılan yasa maddelerinin somut durum için yeniden inşa edilmesi şeklinde ifade eder. Yeniden bir anlam inşa edilmesi bu yorumun keyfi olacağı anlamına gelmez. Yorumcu, bu anlamı yaratırken kendi dil, kültür ve anlam evrenini yaratır. Dolayısıyla bu evreni yaratırken oluşan sınırlarını gerekçelendirmelidir ${ }^{55}$. Hirş’e göre, kararda seçilen yorum tarzının hangi nedenlerden ötürü daha elverişli olduğu gösterilmelidir ${ }^{56}$. Temyiz mercii de gerekçe gösterilmeden yapılan yorumları hukuka aykırı bulmaktadır. Örnek olarak, Yargıtay 6'ncı Ceza dairesi

53 KARAKOÇ, 2007, s. 278.

54 Danıştay, 7. D, T. 25.11.1999, E. 1998/1345, K. 1999/2900, Kazancı Bilgi Bankası.

55 Yorumcunun hukukî yorum yaparken kendi dil, kültür evrenini yaratması yorumun her zaman hukuka uygun olacağı anlamına gelmez. Örneğin, Danıştay bir kamu görevlisi alım ilanında "askerlik görevini tamamlamış olmak" şartının bulunmasından bu ilana sadece kadın adayların başvurabileceği yorumunu yapmış ve sınavı kazanan kadın adayların atanma işlemini iptal etmiştir. Bu karar AİHM tarafında Türkiye'nin mahkûm edilmesine neden olmuştur. bkz. AİHM, Emel Boyraz v. Türkiye, Başvuru No. 61960/08, 02.12.2014; Hülya Ebru Demirel v. Türkiye, Başvuru No. 30733/08, AİHM, 03.12.2018. www.hudoc.echr.coe.int, Erişim:20.10.22021.

56 HİRŞ, 2017, s.109. 
04.02.2002 tarih ve 48/1108 numaralı kararında, çadır kavramını bina içerisinde değerlendirmemiştir. Kararda binanın; "başkalarının girmesine izin verilmediğini gösterecek biçimde dış dünyadan ayrılmış, yanları muhkem surette yapı malzemesiyle örtülmüş̧ üstü kapalı geçici veya sabit, resmi ya da özel yapı" olduğunu belirtip ilk derece mahkemesinin yorumunu hukuka aykırı bularak hükmün isabetli kurulmadığını belirtmiş ve bozma kararı vermiştir ${ }^{57}$. İdare hukuku gibi içtihadi hukuk dallarında gerekçede belirtilen yeni kavramların tanımlanması özellikle önemlidir. Örneğin, Anayasa Mahkemesi idari sözleşme ölçütlerini belirlediği kararında, ölçütlerden biri olarak idareye, “özel hukuk yetkilerini aşan” yetkiler tanınması gerekliliğinden bahsetmiş ancak bu terimi tanımlamamıştır ${ }^{58}$. Bir sözleşmenin idari sözleşme veyahut özel hukuk sözleşmesi sayılmasının hukukî sonuçları farklı olduğundan idarenin bu ayrımı mahkemelerin gösterdiği şekliyle kendiliğinden yapabilmesi gerekir. Bunun için de mahkemenin "özel hukuk yetkilerini aşan yetkiler” gibi muğlak bir kavramı sadece belirtmekle kalmayıp tanımlaması, idareye yol gösterici nitelikte olduğu gibi gerekçe yazım tekniklerine de uygun kabul edilir.

Hâkimin gerekçeye aktardığı yorumu, kanunun hem lafzına hem de konuluş amacına uygun olmalıdır. Hukukçu herhangi bir maddeyi yorum kurallarına uygun bir şekilde yorumladıktan sonra, bulduğu ve kullandığı yorum tarzını mantıkla da ispat etmelidir. Sonucun, maddenin lafzına veya ruhuna ya da çıkarların durumuna uyduğunu ileri sürmek yeterli değildir. Seçilen yorum tarzının hangi nedenlerden ötürü daha elverişli bulunduğu gösterilmelidir. $\mathrm{Bu}$ "ispat", mantıki ve inandırıcı olmalıdır 59 . Gerekçe, dosyanın içeriği ile uyumlu olmalı, gerekçede tarafların taleplerine esas olan, iddia ve savunmalara dayanak oluşturan önemli vakaların tümü değerlendirilmeli ve bu, kararın gerekçesinde gösterilmelidir. Gerekçenin uzun veya kısa olması önemli değildir, önemli olan içermesi gereken bütün unsurları içermesidir ${ }^{60}$.

57 UZUN, 2007, s. 363-364.

58 AYM, T. 09.12.1994, E.1994/43, K.1994/42, RG.24.01.1995.AYM Kararlar Bilgi Bankas1

59 HİRS, 2017, s. 105.

60 ÖZEKES, Muhammet, Medeni Usul Hukukunda Hukukî Dinlenilme Hakkı, Yetkin Yayınları, Ankara, 2003. s. 177. 


\section{II.YARGI KARARLARINDA GEREKÇE}

Kararlar, esasen ara kararlar ve nihai kararlar olarak ikiye ayrılarak incelenmektedir ${ }^{61}$. Bu ayrım, karar verildikten sonra hâkimin uyuşmazlığın çözümüne devam edip, etmemesine göre yapılmaktadır. Hâkim, verdiği kararla yürütmekte olduğu yargısal faaliyeti sonlandırıyorsa bu tür kararlar, "nihai karar" olarak adlandırılmaktadır. Nihai karar veren hâkim, bununla yargılamayı usul ya da esasa ilişkin bir sebeple sona erdirmektedir. Buna karşılık hâkim, karar verdikten sonra uyuşmazlığın çözümü için yargılama faaliyetine devam ediyor, o yargılamadan veya davadan elini çekmiyorsa bu kararlar ara kararlardır. Bu ayırım, kanun yollarına başvuru açısından önem taşır. Zira hukukumuzda kural olarak sadece gerçek anlamda nihai kararlara karşı kanun yollarına başvurulabilir. Ara kararlara karşı ise tek başına kanun yollarına başvurulamaz; ara kararların ancak nihai kararla birlikte kanun yolu denetimine tabi tutulabilir ${ }^{62}$.

Anayasa'nın 141'inci maddesi “bütün mahkemelerin”, "her türlü kararları” nın gerekçeli olması gerektiğinden bahseder. Başka bir deyişle, Anayasa, herhangi bir mahkemeye veya mahkemelerin herhangi bir tür kararına "gerekçesizlik" ile ilgili bir istisna getirmemiştir. "Her türlü” ibaresinden anlaşılmaktadır ki, ilk derece mahkemelerinin sadece nihai kararlarını değil ara kararlarını ve hatta direnme kararlarını gerekçe göstererek kaleme almaları gerekir. Yargıtay’a göre, direnme kararlarında, hukuka uygunluk denetimi yapan yüksek mahkemenin hukuka aykırı bularak bozduğu kararının; hukuka uygun olma ve bozma kararının yerinde olmama nedenleri ilk derece mahkemesince tek tek açıklanmalıdır. 63 "Bütün mahkemelerin" ibaresi ise bizi sadece ilk derece mahkemelerinin değil, yüksek mahkemelerin de kararlarını gerekçeli yazması gerektiği sonucuna götürmektedir.

61 PEKCANITEZ, Hakan, Pekcanitez Usul Medeni Usul Hukuku, On iki Levha Yayınları, İstanbul, 2017, s.1970, ATALI Murat / ERMENEK, İbrahim, Medeni Usul Hukuku, Seçkin Yayınları, Ankara, 2019, s.292.

62 ATALI, 2017, s. 1969.

63 Yargitay Hukuk Genel Kurulu, T. 07.05.2014, 4/1121-626, Aktaran; BEKRİ, M. Nedim, "Gerekçeli Karar Hakkı", Ankara Barosu Dergisi, yIL:2014, Cilt: 72, Sayı:3, (s. 205-228), s.225. 


\section{A. Kısa Karar- Gerekçeli Karar Ayrımında Gerekçe}

Yargılama sonunda varılan sonucun ne olduğunu, taraflara yüklenen borçların ve tanınan hakların nelerden ibaret bulunduğunu, varsa hükme karşı kanun yolunun tür ve süresini içeren kararlara kısa karar denir ${ }^{64}$. Gerekçeli karar ise, mahkemeyi, hüküm sonucuna götüren maddî ve hukukî sebeplerin, dayanakların açıklandığı; iddia, savunma, argümanlarının, delillerin tartışılıp değerlendirildiği; mahkeme masrafları, harçları gibi yardımcı taleplerin de hüküm fikrasında karara bağlandı̆̆ı hukukî metindir ${ }^{65}$.

Uygulamada gerek mahkemelerin iş yükünün çok olması gerekse diğer nedenlerle, kararın ayrıntıları ve gerekçeleri daha sonra yazılır. HMK'nın 294'üncü maddesinin 4'üncü fikrasına göre, gerekçeli karar kısa kararın tefhiminden itibaren 1 ay içerisinde yazılmalıdır. Kanun bu 1 aylık süre ile gerekçeli kararın yazılmasında mahkemelerin keyfi davranışlarının önlenmesini, tarafların haklarının ihlal edilmemesini, üst mahkemelere başvuru hakkının sürüncemede bırakılmamasını ve bir an önce, hak arayanlara haklarının teslim edilmesini amaçlamıştır ${ }^{66}$. Bu durumda, şöyle bir soru akla gelebilir; bir hâkim kısa karar verdikten sonra herhangi bir şekilde görevini ifa edemez hale gelirse, kısa kararın gerekçesi nasıl yazılacaktır?

Bununla ilgili geçmişte Yargıtay, her ne kadar kısa karar, hükmün esasına teşkil etse de gerekçeli kararı yazacak olan hâkimin yargılama yapması gerektiğinden bahisle, yeniden bir hüküm kurulması gerektiğini belirtmiştir ${ }^{67}$.

Konuyla ilgili günümüzde HMK ve CMK'da özel düzenlemeler mevcuttur. 6100 sayılı HMK'nın 299'uncu maddesine göre; Hüküm sonucu tefhim edildikten sonra

64 TUTUMLU, 2007, s.46.

65 TUTUMLU, 2007, s. 47.

66 DEMİRCIOĞLU, Yaşar, Medeni Usul Hukukunda insan Hakları ve Adil Yargılanma Güvenceleri, Yetkin Yayınevi, Ankara, 2007, s. 214; ATALI / ERMENEK, 2019, s.308; ERCAN, İsmail: Medeni Usul Hukuku, Yetkin kitabevi, Ankara, 2020, s.319: PEKCANITEZ, 2019, s. 1997.

67 Her ne kadar hükmün esasına kısa karar teşkil etmekte ise de CMUK.nun 260 ve 268. maddeleri uyarınca Yargıtay denetimine de imkan verecek biçimde, maddî olaylarla sübut nedenlerinin kuşkuya yer vermeyecek şekilde açıklanarak, gerekçeleri ile birlikte gösterilmesi gerektiğinden, bu durumun CMUK.nun 308. maddesinin açık hükmü muvacehesinde kanuna muhalefet halini oluşturması ve CMUK'nun 260, 261, 268 ve 308'inci maddelerine uygun düşecek ve kısa kararı da kapsayacak yeni bir hüküm kurulması lüzumu” Yargitay 2.CD, T. 24.03.1995, E. 1995/2419 K. 1995/3803, Kazancı Bilgi Bankası. 
gerekçeli karar imzalanmadan, hâkim ölür veya herhangi bir sebeple imzalayamayacak hâle düşerse, yeni hâkim, tefhim edilen hükme uygun olarak gerekçeli kararı bizzat yazarak imzalar. HMK' nın ilk halinde olan bu düzenleme, CMK'ya 2016 tarihinde, 6763 sayılı Kanun ile 232. maddeye 5'inci F1kra olarak eklenmiştir. Söz konusu hükme göre, Hüküm sonucu tefhim edildikten sonra gerekçeli karar imzalanmadan hâkim ölür veya herhangi bir sebeple kararı imzalayamayacak hâle düşerse, yeni hâkim, tefhim edilen hükme uygun olarak gerekçeli kararı bizzat yazarak imzalar.

Kısa karar terimi, hukuk sistemimize uygulama sonucunda girmiştir. Zira Türk Yargılama sisteminde yaygın uygulama, mahkemelerin önce hükmü açıklamaları aradan belli bir süre geçtikten sonra gerekçeli kararı yazmalarıdır. Hükmü açıklayıp, gerekçesi henüz yazılmadan hâkimin görevini ifa edemez hale gelmesi durumunda, gerekçenin yeni hâkim tarafından verilmesi bazı sakıncalara sebep olabilecektir. Ceza ve hukuk yargılaması, duruşmalı yargılama düzenleridir. Uyuşmazlık ile ilgili yargılama faaliyetine katılmamış, tanıkları, mağduru, sanığı ve diğer tarafları dinlememiş ve sadece dosya üzerinden uyuşmazlığa vakıf olan hâkimin, gerekçeli kararı yazdırmaya zorlanması, hukuk tekniği ve gerekçe yazım tekniği açısından hukuka aykırıdır.

Hâkimin hangi zorunlu nedenlerle gerekçesini sonradan yazdığını kararında belirtmesinin keyfiliği önleyeceği ve hukukî dinlenilme hakkına uygun olacağı doktrinde belirtilmektedir. Buna göre gerekçenin hükümle birlikte, zorunlu hallerde ise kısa süre içinde yazılmasının bir önemi de karar aleyhine verilen tarafın, gerekçe ortaya çıkıncaya kadar mahkemenin kararına şüphe ile yaklaşmasının önüne geçmek ve tarafın kanun yoluna başvuru imkânını da geciktirmemektir ${ }^{68}$. Gerekçeli karar, hüküm fikrası ile maddî vakalar arasında köprü görevi yapar. Bu sebeple gerekçeli karar ile kısa kararın birbirine uygun olması gerekir ${ }^{69}$. Nitekim Yargıtay kararlarında, kısa kararın açıklanan hükmün ve gerekçeli kararın çelişsili olmasını bozma nedeni olarak kabul etmektedir ${ }^{70}$. HMK'nın 353'üncü maddesinin 1'inci fikrasının b bendinin 2 numaralı alt bendinde kararın

68 ÖZEKES, 2003, s. 175.

69 DEMIRCIOĞLU, 2007, s. 215.

70 Yargıtay İçtihadı Birleştirme Kararı, T.10.04.1992, E.19917, K.1992/4; Yargıtay 6. HD, T. 02.04.2007, E. 2006/1755, K. 2007/3680; Aktaran, BEKRİ, 2014, s.225. 
gerekçesinde hata edilmesi istinaf sebebi olarak düzenlenmiştir. Düzenlemeye göre istinaf mahkemesi hatayı düzelterek esas hakkında karar verecektir.

\section{B. Ara Kararlarda Gerekçe}

Ara kararlar, yargılamaya (davaya) son vermeyen, bilâkis onu yürütmeye, ilerletmeye yarayan kararlardır. Hâkim, yargılamayı yürütmek (ilerletmek) için davada birçok ara karar verebilir. Bütün bu kararların ortak niteliği, hâkimin ara kararı ile davadan (işten) elini çekmeyip, davaya devam etmesidir ${ }^{71}$.

Türk yargılama hukukunda, yargılamayı sona erdirmemekle birlikte, bazı tedbirler öngören kararlar da bulunmaktadır. Geçici hukukî koruma ${ }^{72}$ getiren bu kararlara, ceza yargılamasında tutuklama kararlarını, idari yargılama hukukunda yürütmenin durdurulmasının, hukuk muhakemesinde ise ihtiyat-i tedbir kararlarını örnek olarak verebiliriz. Bu tür kararların gerekçeli verilmesinin, ihsas-1 rey teşkil edeceği endişesi ile hâkimlerin gerekçe göstermekten imtina edeceği sorunu akla gelmektedir. Bu konuda Usul Kanunlarında farklı düzenlemeler mevcuttur.

CMK' nın, 100 ve 101'inci maddelerine göre, maddî gerçeğe ulaşmak amaciyla tutuklama tedbiri uygulanabilir. Anayasa'nın 141'inci maddesinin 3'üncü fikrası, CMK' nın 34, 100 ve 101'inci maddelerine göre, tutuklama kararları mutlaka gerekçeli verilmelidir. Bir tedbir olan tutuklama ancak, masumiyet karinesine sahip olmakla birlikte, kuvvetli suç şüphesini gösteren olgular altında bulunduğu söylenen şüpheli veya sanığın, adaletten kaçma veya delil karartma ihtimalini gösteren somut şüphelerinin varlığı halinde verilebilir. Tutuklama, kişi hürriyetinin geçici olarak sınırlandırılmak suretiyle yargılama için muhtemel olumsuzlukların önüne geçilebilmesi, maddî gerçeğe ve adalete ulaşılabilmesini sağlamak amacıyla uygulanabilecektir ${ }^{73}$. Uygulamada ise genellikle, hâkimin tutuklama kararı verirken delilleri takdir edemeyeceği ve kovuşturma sırasında değerlendirilmesi gereken delillerin soruşturma aşamasında nöbetçi hâkim

71 KURU, Baki, Hukuk Muhakemeleri Usulü, 6. Basım, Cilt: 3, Demir- Demir Yayınevi, İstanbul, 2001, s. 2996.

72 ÖZEKES, Muhammet, “İhtiyati Haciz Kararlarının Gerekçeli Olması ve Kanun Yoluna Başvuru”, Prof. Dr. Yavuz Alagonya İçin Armağan, 2007, (s 469-484), s. 471.

73 ŞEN, Ersan / ÖZDEMIR Bilgehan, "Tutuklama Uygulamalarına Bir Bakış: Tutuklamada Gerekçesizlik Sorunu”, İstanbul Barosu Dergisi, Y11:2013, Cilt:87, Say1:1, (s. 15- 24), s. 16. 
tarafından yapılmasının ihsas-1 reye aykırı olduğu ileri sürülmekte ve neticede gerekçesiz tutuklama kararları verilmektedir ${ }^{74}$. Ancak başka bir görüşe göre, tutuklama, tutukluluğun devamı ve adli kontrole ilişkin kararlarda her bir şüpheli ve sanıkla ilgili olarak somut gerekçe gösterilmesi, bu tedbirlerin yargılamanın esası ile ilgili olmaması sebebiyle ihsas1 rey, yani hâkim veya mahkemenin önceden görüş bildirmesi niteliğinde değildir. Bu nedenle, hâkim veya mahkemenin somut gerekçe göstermekten kaçınmaması gerekir ${ }^{75}$.

İdari Yargıda yürütmenin durdurulması müessesesi, İYUK'un 27'nci maddesinde ve Anayasa'nın 125'inci maddesinin 5'inci fikralarında düzenlenmiştir. Bu hükümlere göre, yürütmeyi durdurma kararları verilebilmesi için, idari işlemin uygulanması halinde telafisi güç veya imkânsız zararlarının doğması ve idari işlemin açıkça hukuka aykırı olması gerekir. Mahkemece yürütmenin durdurulmasına karar verilmesi halinde, kararın gerekçeli olması zorunluluğu bu maddelerde açıkça düzenlenmiş; ancak yürütmenin durdurulması talebinin reddine karar verilmesi halinde bu kararın gerekçeli olması hususunda bir düzenlemeye gidilmemiştir. Uygulamada, mahkemeler maddenin lafzından hareketle yürütmenin durdurulması kararlarının gerekçelerini belirtmekte, ancak ret kararlarında yalnızca “IYYUK 27/2'de öngörülen koşulların birlikte gerçekleşmediği anlaşıldığından yürütmenin durdurulması isteminin reddine" karar vermektedirler. Kanun hükmüne yapılan bu atıflar, gerekçe değil, hukukî sebep niteliğindedir ${ }^{76}$. Yürütmenin durdurulması kararında hem işlemin açıkça hukuka aykırılığı hem telafisi güç veya imkânsız zararların doğması koşullarının gerçekleştiği konusunda gerekçeli karar vermek, iptal davasının esasını karara bağlamak demektir. Henüz taraflar, sav ve savunmalarını yapmadan, davanın esasını etkileyecek nitelikte, adı

74 YENISEY, Feridun, "Tutuklama Kararında Gerekçe Sorunu”, Kazancı Hakemli Hukuk Dergisi, Y1l:2009, Sayı: 53, (s. 174- 185), s. 175. Ayrıca bkz. CENTEL, Nur, "İnsan Hakları Avrupa Mahkemesi Kararları Işı̆̆ında Tutuklama Hukukuna Eleştirel Yaklaşım”, MÜHF-HAD, Cilt:17, Sayı:.1-2, (s.4993). ŞENTUNA, Mustafa Tarık, 5271 Sayılı Ceza Muhakemesi Kanunu'nda Tutuklama ve Adli Kontrol, Adalet Yayınları, Genişletilmiş 2. Basım, Ankara, 2007.

75 ŞEN/ÖZDEMIR, 2013, s. 17. Medeni Usul Hukukunda geçici koruma tedbirleri ile ilgili bkz ÖZEKES, Muhammet, "Medeni Usul Hukukumuzda Yok Hüküm ve Etkisiz Hüküm”, Yargıtay Dergisi, Ekim 2000, Cilt: 26, Say1: 4, (s.661-699).

76 GÜRSOY, Mustafa, "Yürütmenin Durdurulması Kararında Gerekçesizlik Sorunu", Terazi Hukuk Dergisi, Y11:2007, Say1: 14, (s. 61-66), s. 63. 
ne olursa olsun karar verilmesi, yargılama işlevi ile bağdaşmamaktadır ${ }^{77}$. Ancak yürütmenin durdurulması tıpkı tutuklama gibi bir mahkeme kararıdır. İhsas-1 rey müessesi, hâkimin bir mahkeme kararı olmadan görüşünü belli etmesidir. Oysaki kanunlarda öngörülmüş bir yargı kararı vermesi hâkimin yasal yükümlülügüüür. Bu sebeple, yürütmenin durdurulması kararlarının gerekçelendirilmemesi hukuka aykırıdır.

Yukarıda bahsedilen geçici hukukî korumalar, etkin bir hukukî koruma için gerekli ve zorunludur. Bir hakla ilgili hukukî koruma talebi bir bütün olarak düşünüldüğünde, geçici hukukî koruma, bu bütün içinde asıl parçanın korunmasına ve etkinliğinin sağlanmasına yönelik bir bölümü ifade etmektedir. Şüphesiz asıl için tanınan bir haktan, onun parçasını mahrum bırakmak söz konusu olamaz ${ }^{78}$.

Gerekçe, kararın niteliğine göre değişebilir. Örneğin, nihai kararlarda daha geniş kapsamlı gerekçe bulunmakta iken, ara kararlarda gerekçe daha kısa olabilir. Ancak kararın niteliğinden bağımsız olarak, bütün kararların ortak özelliği gerekçeli olarak kaleme alınmalarıdır. Aksi halde, ara kararlar şeklen hukuka aykırı olacak ve istenen sonucu sağlamayacaktır. Hatta kanun yolu mercilerinde ve heyet halinde çalışan mahkemelerde, hâkimlerin karşı oyları dahi gerekçeli yazılmalıdır. Gerekçenin ne kadar ayrıntılı olursa o kadar tatmin edici olduğu düşüncesi bir sorun olarak karşımızdadır. Kanun koyucunun oldukça ayrıntılı gerekçeler istediği açıktır. Ancak, geçici koruma tedbirlerinde, uzun ve ayrıntılı gerekçeler istenmesi maalesef hâkimlerin bu tedbirleri vermekten imtina etmesi sonucunu doğurabilmektedir ${ }^{79}$.

\section{GEREKÇENİN NITTELİĞİ}

Gerekçesizlik, gerekçenin hiç yazılmamış olması haline münhasır değildir. Uygulamada daha çok rastlanan ve eleştirilere neden olan konu, yazılmış olan gerekçelerin hukuk tekniği bakımından yetersiz kalması veyahut kalıplaşmış formül

77 GÖZÜBÜYÜK Şeref/TAN Turgut, İdare Hukuku Cilt: II, Turhan Kitapevi, Ankara, 2012, s. 174.

78 ÖZEKES, 2007, s. 470.

79 TEKINSOY, Ayhan, İdari Yargılama Hukukunda Yürütmenin Durdurulması, Savaş Yayınevi, Ankara, 2013., s. 172. 
ifadelerden ibaret olmasıdır ki buna sözde (görünürde) gerekçe denilmektedir ${ }^{80}$. Ökçesiz ise, görünürde gerekçeyi, "kılıf gerekçe" olarak adlandırmıştır. Yazara göre, bir gerekçenin kılıf olup olmadığı, bu gerekçe ile verilmiş bir zararın bulunup bulunmadığının, varsa, zararın niteliğinin ve hukuk devleti değerleriyle ölçüldüğünde göreceği koruma düzeyinin saptanmasıyla anlaşılır ${ }^{81}$.

Gerekçenin, kararın ulaşmak istediği amaç ile uygun ve orantılı olması gerekir. Anayasa mahkemesi bu konuyla ilgili olarak" ilgili ve yeterli" kavramlarını kullanmıştır. Mahkemeye göre “...yapılacak değerlendirmelerin temel ekseni, müdahaleye neden olan Derece Mahkemelerinin kararlarında dayandıkları gerekçelerin ifade özgürlüğünü kısıtlama bakımından 'demokratik bir toplumda gerekli' ve 'ölçülülük ilkesi' ne uygun olduğunu inandırıcı bir şekilde ortaya koyup koyamadığı olacaktır. (Mehmet Ali Aydın [GK], B. No: 2013/9343, 4/6/2015, § 73). Bu nedenle somut başvuruda müdahalenin arzulanan hedeflere uygun olup olmadığının ve RTÜK ile Derece Mahkemelerinin kararlarında belirtilen gerekçelerin" ilgili ve yeterli" olup olmadığının değerlendirilmesi gerekmektedir..." ${ }^{\prime 82}$. Anayasa Mahkemesi'ne göre, gerekçenin uygun ve orantılı olması, yargı kararının arzuladığı amaca yönelik sonuç doğurmasıdır. Yargıtay da gerekçe ve sonucun mantıksal bir uyum içinde olması gerektiğini belirtmektedir: “...Yasanın aradığı anlamda oluşturulacak kararların hüküm fikralarının açık, anlaşılır, çelişkisiz, uygulanabilir olmasının gerekliliği kadar; kararın gerekçesinin de, sonucu ile tam bir uyum içinde, o davaya konu maddî olguların mahkemece nasıl nitelendirildiğini, kurulan hükmün hangi nedenlere ve hukuksal düzenlemelere dayandırıldığını ortaya koyacak; kısaca, maddî olgular ile hüküm arasındaki mantıksal bağlantıyı gösterecek nitelikte olması gerekir... ${ }^{83}$ AİHM de ulusal mahkemelerin kararlarının, yapılan müdahaleyi yeterli ve ilişkili bir gerekçe ile temellendirilmesi gerektiği kanaatindedir ${ }^{84}$.

80 ALP, Mustafa, "Anayasa Hukuku Açısından Mahkeme Kararlarında Sözde (Görünürde) Gerekçe”, Prof. Dr. Mahmut Tevfik Birsel'e Armağan, İzmir; Dokuz Eylül Üniversitesi Yayını, (s. 425-441), s. 426.

81 ÖKÇESIZ, 2004, s. 12

82 AYM, R.V.Y. A.Ş. Başvurusu, T. 14.10.2015 Başvuru Numarası: 2013/1429, RG.3.12.2015 No: 29551.

83 Yargitay, 8. HD T. 10.07.2012, E. 2012/5106 K. 2012/6952. Kazanc1 Bilgi Bankası.

84 AïHM, Sorguç/ Türkiye Davası, T.23.06.2009, Başvuru Numarası: 17089/03 www.hudoc.echr.coe.int e.t.: 12.05 .2018 . 
Gerçek bir gerekçe, hukuksal kalıplar ile olaylar arasındaki ilişkiyi mantıksal tutarlılık içerisinde, boşluk bırakmadan kurar. Bunun için gerekli tüm rasyonel adımları atar ve sonuç hükmüne ulaşır ${ }^{85}$. Gerekçe, hâkimi muayyen bir hükmü vermeye sevk eden mantık yolunu, aralıksız ve boşluksuz gösterebilmelidir ${ }^{86}$. Fiili ve hukukî meselelere göre ayrı ayrı yazılmalıdır. Fiile ilişkin gerekçe, hukukî meselelerin gerekçesine temel teşkil etmektedir. Hüküm, sadece gerekçenin yokluğunda, batıl değildir; aynı zamanda gerekçe ile hükmün çelişkili olması halinde, usulüne uygun verilmiş bir hükümden söz edilemez ${ }^{87}$. Genel ve soyut bir ifade olan kanun ile maddî olaya ilişkin yargının birbiri ile ilişki kurulması ile sonuç ortaya çıkar. Bu ilişkinin kararda mutlaka gösterilmesi gerekir. Örneğin, hırsızlığın ne olduğunun belli edilmesi ile A'nın da bu çerçevede hırsız olduğunun açıkça belirtilmesi gerekir ${ }^{88}$. Kararların gerekçeli olması yargılamada ileri sürülen her türlü iddia ve savunmaya ayrıntılı şekilde yanıt verilmesini gerektirmemektedir. Ancak davanın taraflarından birinin, ayrı ve açık bir yanıt verilmesini gerektiren, usul veya esasa dair iddia ve itirazlarının cevapsız bırakılmış olması gerekçeli karar hakkının gerekleri ile bağdaşmamaktadır. Örneğin, bilirkişi raporundaki çelişkinin giderilmesi yönündeki itirazların etkili bir şekilde karşılanmak yerine itiraz edilen bilirkişi raporundaki ifadelerin tekrarı ile yetinilmesi de adil yargilanma hakkının ihlalidir ${ }^{89}$.

Gerekçe, anayasal ve yasal bir zorunluluktur ve kararlarda tatmin edici bir gerekçenin bulunmaması kesin hukuka aykırılık hali yani mutlak bozma sebebidir ${ }^{90}$. Zira temyiz veya istinaf yolunda ilk derece mahkemesi kararı onanır veya hukuka uygun bulunursa, kanun yolu merciinin ayrıca detaylı bir açıklama yapması somut olay için beklenmeyebilir. $\mathrm{Bu}$ aşamada, sağlam temellendirilmiş bir gerekçe, uyuşmazlıkla ve

85 ÖKÇESİ, 2004, s.13.

86 EREM, Faruk, Diyalektik Açıdan Ceza Yargılaması Hukuku, 6. Baskı, Işıı Yayınları, 1986, s. 503'ten Aktaran; KARAKOÇ, 2007, s. 277.

87 KARAKOÇ, 2007, s. 278.

88 UZUN, 2007, s. 366.

89 AYM, Buğrahan Babacan Başvurusu, T. 09.09.2015, Başvuru Numarası: 2014/2388, e.t. 12.05.2018; Aynı yönde görüş için bakınız: ŞAHIN/ GÖKTÜRK, s. 185.

90 ŞAHIN, Cumhur/GÖKTÜRK, Neslihan, Ceza Muhakemesi Hukuku II, Seçkin Yayınevi, 2016, s. 186. 
maddî olaylarla ilgili temel ilke ve esasların konulması açısından önemlidir. AİHM de temyiz hakkının sözleşmece güvence altına alınmadığı düşüncesi ile temyiz merciince verilen kararların gerekçeli olmayışını ihlal kabul etmemekte, üst mahkemenin sadece ilgili yasa maddesine gönderme yapmasını ihlali önleme bakımından yeterli görmektedir. Komisyona göre; iç hukuk yetkili bir mahkemenin kararının temyiz edilmesini kabul etmekte ise, ister temyiz çok önemli bir hukukî konuyu ortaya çıkarsın ve isterse bunun başarılı olma şansı olmasın üst derece mahkemelerinin sadece ilgili maddeye gönderme yapmasını, ihlali önleme bakımından yeterli bulunmaktadır ${ }^{91}$. Bunun yanında AİHM'ye göre, üst mahkemenin kendisine yöneltilen itirazları yeterli düzeyde incelemesi gerektiğinden, ayrıca başvuruyu reddetmesi halinde taraflara, başvuru haklarını etkin kullanmalarını sağlayacak gerekçenin sunulması gerekmektedir ${ }^{92}$. Tatmin edici ve tutarlı yazılmamış, detaylı araştırma yapılmadan hüküm kurulmuş bir ilk derece mahkemesi kararına, kanun yolu tarafından atıf yapılarak kararın onanmasını Anayasa Mahkemesi, gerekçeli karar hakkının ihlali olarak görmüştür ${ }^{93}$.

AİHM temelde, açık bir keyfilik görüntüsü olduğu veya açıkça ya da makul bir biçimde gerekçe gösterilmediği durumlarda gerekçenin niteliğini tartışmaktadır ${ }^{94}$. Bu

91 ŞEKER, Hilmi, "Strazburg Yarg1 Kararlarında Doğru, Haklı, Yasal ve Makul Gerekçe Biçimleri”, Ankara Barosu Dergisi, Y11:2007, Cilt: 2, s.183.

92 Onur Durmuş ve Diğerleri / Türkiye, B. No:31575/07§46" Adil yargılanma kavramı, kararını kısaca gerekçelendiren yerel bir mahkemenin, ister bir alt mahkeme tarafindan sunulan gerekçeleri dahil etmiş olsun ister başka bir şekilde olsun, kendisine sunulan temel sorunlarl gerçekten inceleyen ve bir alt dereceli mahkemenin sonuçlarını sadece onaylamakla yetinmeyen bir mahkeme olmasını gerektirmektedir. Bir üst mahkeme, başvurunun reddedilmesi için bir alt mahkemenin kararını destekleyen gerekçeleri geri almakla yetindiğinde, bir alt mahkemenin veya makamının, tarafların başvuru haklarını etkin bir şekilde kullanmalarını sağlayacak gerekçeleri sunması gerekir” Aynı yönde karar için bkz. Helle/Finlandiya, No. 20772/92, § 55-60.

93 “Anayasa'nın 40'ınc maddesinde yer alan ve idari işlemlerde ilgili kişilerin hangi kanun yolları ve mercilerine başvuracağının ve bunun sürelerinin belirtilmesinin zorunlu olduğu kuralına rağmen dava konusu edilen işlemde bu hususlara yer verilmediği için süresi içinde dava açamadiğına yönelik başvurucu iddiasının ciddi olduğu ve İlk Derece Mahkemesi tarafindan bu iddia değerlendirilemediğ $i$ için kanun yolu aşamasında ayrıca değerlendirilmesi gerektiği ancak Danıştay Yedinci Dairesince ayrı bir değerlendirme yapılmayarak Illk Derece Mahkemesi kararına atıf yapılmak suretiyle temyiz isteminin ve daha sonra karar düzeltme talebinin reddedildiği oysa bu iddianın atıf yapılmak suretiyle karşılanacak iddia niteliğinde olmadı̆̆ı, temyiz merciince bu iddianın açık bir şekilde kararlarında değerlendirilmediğ $i$ ve karşılanmadığ görülmektedir. Bu nedenle yargllama süreci bir bütün olarak değerlendirildiğinde başvurucunun gerekçeli karar hakkının ihlal edildiği sonucuna varılmıştır” AYM, Denktaş Nakliyat Turizm Ltd. Şti. Başvurusu, T. 15/10/2015, Başvuru Numarası: 2013/3963, e.t.12.05.2018.

94 ŞEKER, 2007, s. 449. 
nedenle, AİHM kararlarına göre, gerekçeli karar kuralı mutlak bir kural değildirr ${ }^{95}$. Kararın gerekçeli olması konusunda gerek Anayasa Mahkemesi gerekse AİHM, mahkemelerin takdir hakkını sonsuz bir döngüde sınırlandırmaktan kaçınmaktadır. Zira her iki mahkeme de temyiz mercii değildir. Yukarıda izah edildiği üzere, kararların gerekçesiz olması veya tatmin edici gerekçeden yoksunluk temyizde mutlak bir bozma nedenidir. Ancak Anayasa Mahkemesi ve AİHM, konunun adil yargılanma hakkı ile bağlantısını sınırlandırarak kurmuşlardır. Buna göre, genellikle, açık bir keyfilik görüntüsü olduğu zaman veya açıkça makul olmayan bir biçimde gerekçe gösterilmediği zaman, gerekçenin niteliği tartışılmaktadır ${ }^{96}$. Ancak, mahkemelerin uyuşmazlığın çözümünde takdir hakkının bulunması, uyuşmazlığın çözümünün tatminkâr olmayacağı sonucunu doğurmamalıdır. Örneğin, Anayasa Mahkemesi'ne göre, “...aynı hususta daha önce çıkan kararlardan farklı bir hüküm kurulması halinde, mahkemelerce, bu farklılaşmaya ilişkin makul bir açıklama getirilmesi gerekmektedir"97. Anayasa Mahkemesi, diğer bir kararında, aynı konuyu şu şekilde vurgulamıştır: “...Derece mahkemeleri, dava konusu maddî olay ve olguların kanıtlanmasını, delillerin değerlendirilmesini, hukuk kurallarının yorumlanması ve uygulanmasını, uyuşmazlıkla ilgili vardı̆̆ s sonucu, sonuca varırken kullandiğı takdir yetkisinin sebeplerini makul bir şekilde gerekçelendirmek zorundadır. Bu gerekçelerin oluşturulmasında açık keyfîlik görüntüsü olmaması ve makul bir biçimde gerekçe gösterilmesi hâlinde adil yargılanma hakkının ihlalinden söz edilemez"98.

Türk Medeni Kanun'un 1'inci maddesinde hâkimlerin kararlarını verirken bilimsel görüşlerden faydalanabileceği hüküm altına alınmıştır. Öğretide dile getirilen görüşler hâkimler için bağlayıcı değildir; fakat taşıdığı önem dolayısıyla kanun koyucu hâkime böyle bir yetki vermiştir. Kullanılan bilimsel görüşlerin gerekçeyi güçlendirdiği muhakkaktır; ancak bu yetki kullanılırken bazı sorunlar ortaya çıkmaktadır. Hirş’e göre,

95 ALP, 2001, s.437.

96 İNCEOĞLU, Sibel: İnsan Hakları Avrupa Mahkemesi Kararlarında Adil Yargılanma Hakkı, Beta Yayınları, İstanbul, 2002, s. 311.

97 AYM, Türkan BAL Başvurusu, T. 06.01.2015, Başvuru Numarası: 2013/ 6932, RG. 09.05.2015 No:29350, e.t. 12.05. 2018.

98 AYM, Afitap SALMAN Başvurusu, Tarih: 11.11.2015, Başvuru Numarası: 2013/ 2105, RG. 17.12.2015 No: 29565 , e.t. 12.05.2018. 
herhangi bir hukuk profesörünün düşüncesine veya teorisine soyut olarak dayanmak yeterli sayılamaz. Şu veya bu düşünce ya da teoriye neden katılındığı, tam bir gerekçe ile açıklanmalıdır. İncelenen uyuşmazlık hakkında, birbirinden ayrı düşünce ve teoriler varsa, bunların hepsini sayarak hangisine iştirak, hangisinin ise reddedildiği inandırıcı sebeplerle anlatılmalıdır. Tamamen özerk bir fikir savunuluyor ise, bu fikir gayet esaslı bir tarzda, delilli sebeplerle aydınlatılmalıdır ${ }^{99}$.

Anayasa'nın ve yukarıda detaylı olarak belirttiğimiz üzere, usul kanunlarının ilgili hükümleri gereği, heyet halinde çalışan mahkemelerde gerekçede mutlaka karşı oylara veya azınlık görüşlerine de yer verilmelidir. Çünkü karar, çoğunluk ve azınlık görüşleri ile bir bütündür. Bu durum aynı zamanda, karşı oy bildiren hâkimlerin, gerekçe yazma konusunda sorumluluk hissetmelerini de sağlayacaktır ${ }^{100}$.

\section{ADİL YARGILANMA HAKKI VE GEREKÇELİ KARAR}

Adil yargılamanın en temel özelliği kararların gerekçesidir. Kişilerin hangi karara ne için muhatap olduğunu bilmesi ve anlaması vazgeçilmez ${ }^{101}$. Avrupa İnsan Hakları Sözleşmesi (AİHS)'nin 6'ncı maddesinde adil yargılanma hakkı düzenlenmiştir ${ }^{102}$. Madde lafzında, gerekçeli karar hakkının adil yargılama hakkının bir unsuru olduğu açıkça zikredilmese de gerek AİHM gerekse AYM kararların gerekçelerinde hukuka

99 HíRŞ, 2019, s. 91.

${ }^{100} \mathrm{Bu}$ konuda detaylı bilgi için bkz. YÜCEL, 2003, s. 168 vd.

101 İnsan Hakları Eylem Plan1, 2021, s.29, https://rayp.adalet.gov.tr/resimler/1/dosya/insan-haklari-ep0203-202115-14.pdf, Erişim Tarihi: 03.03.202

102 AİHS M. 6/1 "Herkes davasının, medeni hak ve yükümlülükleriyle ilgili uyuşmazlıklar ya da cezai alanda kendisine yöneltilen suçlamaların esası konusunda karar verecek olan, yasayla kurulmuş, bağımsız ve tarafsı bir mahkeme tarafindan, kamuya açık olarak ve makul bir süre içinde görülmesini isteme hakkına sahiptir. Karar alenî olarak verilir. Ancak, demokratik bir toplum içinde ahlak, kamu düzeni veya ulusal güvenlik yararına, kü̧̈üklerin çıkarları veya bir davaya taraf olanların özel hayatlarının gizliliği gerektirdiğinde veyahut, aleniyetin adil yargılamaya zarar verebileceği kimi özel durumlarda ve mahkemece bunun kaçınılmaz olarak değerlendirildiği ölçü- de, duruşma salonu tüm dava süresince veya kismen basina ve dinleyicilere kapatılabilir.

Adil yargılanma hakkı, 1982 Anayasasının "Hak Arama Hürriyeti” başlıklı 36'ncı Maddesinde 1'inci fikrasında düzenlenmiştir. Madde hükmüne göre;" Herkes, meşrû vasita ve yollardan faydalanmak suretiyle yargı mercileri önünde davacı veya davalı olarak iddia ve savunma ile adil yargılanma hakkina sahiptir". 
aykırılık olması halini adil yargılanma hakkının ihlali olarak değerlendirmektedir ${ }^{103}$. Danıştay da aynı görüştedir: "mahkeme tarafından önüne gelen bir davada, uyuşmazlığın özüne yönelik bir incelemenin yapılması, uyuşmazlığın sadece şekli olarak ele alınması sonucunu doğuracak bir yaklaşımdan uzaklaşılması, adil ve aleni olarak yargılanma hakkını öngören bir yargılamanın da gerçekleşmesini temel ilke olarak alan bir hak" olarak tanımlamaktadır ${ }^{104}$. Aynı kararda mahkeme, adil yargılanma hakkı ve mahkemeye erişim hakkı ile kararların gerekçeli olması arasındaki bağlantıyı şöyle kurmuştur: "Bir davada mahkemece verilen kararın adil bir karar olup olmadı̆̆ının göstergelerinden birisi de kararın gerekçe ihtiva etmesidir. Gerekçeli karar hakkı belirli bir davada başvurucu tarafindan ileri sürülen hukukî meseleler ve maddî vakaların tespitini gerektirmesi nedeniyle, yapısal olarak mahkemeye erişim hakkı kapsamına girmektedir”.

Mahkeme kararlarının gerekçeli olması adil yargılanma hakkının unsurlarından birisi olmakla beraber, bu hak yargılamada ileri sürülen her türlü iddia ve savunmaya ayrıntılı şekilde yanıt verilmesi şeklinde anlaşılamaz. AİHM’ye göre mahkemeler kararlarını gerekçeli olarak yazmak yükümlülügü altında olmakla birlikte, bundan tarafların her iddiasına karşı ayrıntılı cevap verilmesi gerektiği sonucu çıkarılmamalıdır. Bununla birlikte mahkeme, davanın sonucunu temelden etkileyecek bir iddia ya da savunma varsa mahkeme kararında özellikle bunun üzerinde durması gerektiği fikrindedir ${ }^{105}$. Nitekim AİHM, Boldea-Romanya ${ }^{106}$ kararında" ... adil yargılanmanın bir gereği de mahkeme kararlarının gerekçeli olmasıdır. Gerekçede, mahkemenin taraflara

103 "Yapılan yargılama sırasında tanık dinletme hakkı da dâhil olmak üzere delillerin ibrazı ve değerlendirilmesi adil yargllanma hakkının unsurlarından biri olarak kabul edilen silahların eşitliği ilkesi kapsamında kabul edilmekte olup, bu hak ve gerekçeli karar hakkı da makul sürede yargılanma hakkı gibi adil yargllanma hakkının somut görünümleridir. Anayasa Mahkemesi de Anayasa'nın 36'ncı maddesi uyarınca inceleme yaptığı birçok kararında, ilgili hükmü Sözleşme’nin 6'ncı maddesi ve AIHM içtihadı ışı̆̆ında yorumlamak suretiyle, gerek Sözleşme 'nin lâfzî içeriğinde yer alan gerek AIHM içtihadıyla adil yargılanma hakkının kapsamına dâhil edilen gerekçeli karar hakkı ve silahların eşitliği ilkesi gibi ilke ve haklara, Anayasa'nın 36'ncı maddesi kapsamında yer vermektedir". AYM, Adalet Mehtap Buluryer Başvurusu, T. 16.10.2017, Başvuru Numarası: 2013/5447, § 36, e.t. 12.05.2018. Ayrıca bkz. Boldea-Romanya, 15.02.2007, Başvuru Numarası: 1997/02, www.hudoc.echr.coe.int erişim: 12.05.2018.

104 Danıştay 6. Daire T. 24.9.2014 E. 2013/4202 K. 2014/5616, Kazancı Bilgi Bankası.

105 İNCEOĞLU, 2002, s. 308.

106 Boldea-Romanya, 15.02.2007, Başvuru Numarası: 1997/02, www.hudoc.echr.coe.int erişim: 12.05.2018. 
kanun yoluna başvurma hakkı verebilmek adına esas sorunları incelemeli ve kararını dayandırdıkları gerekçeleri yeterince açık olarak ve basit bir anlatımla belirtmelidirler" diyerek, gerekçede belirtilmesi gereken hususları açıklamıştır. AİHM'ye göre ulusal mahkemeler kararlarının yapısı ve içeriği açısından takdir yetkisine sahiptir; fakat kararlarının dayanaklarını yeterli açıklıkta belirtmek zorundadırlar ${ }^{107}$. Bu nedenle, gerekçe gösterme zorunluluğunun kapsamı kararın niteliğine göre değişebilir. Bununla birlikte başvurucunun ayrı ve açık bir yanıt verilmesini gerektiren usul veya esasa dair iddialarının cevapsız bırakılmış olması bir hak ihlaline neden olacaktır. Gerekçenin ayrıntısı davanın niteliğine göre değişmekle birlikte kararın hüküm kısmına dayanak oluşturacak hukukî bir gerekçenin kısa ve özet de olsa bulunmasının zorunlu olduğu açıktır ${ }^{108}$. Anayasa Mahkemesi, bu durumu şu şekilde ifade etmektedir: “...mahkemeler, kararlarını hangi temele dayandırdıklarını yeterince açık olarak belirtme yükümlülüğ̈̈ altındadırlar. Mahkemelerin bu yükümlülüğ̈̈, yargılamada ileri sürülen her türlü iddia ve savunmaya, karar gerekçesinde ayrıntıl şekilde yanıt verilmesi şeklinde anlaşılamaz. $B u$ nedenle, bir kararda tam olarak hangi unsurların bulunmasi gerektiği, davanın niteliğine ve koşullarına bağlıdır. Bununla birlikte muhakeme sırasında açık ve somut bir biçimde öne sürülen iddia ve savunmalar davanın sonucuna etkili olması, başka bir deyişle davanın sonucunu değiştirebilecek nitelikte olması halinde, davayla doğrudan ilgili olan bu hususlara mahkemelerce makul bir gerekçe ile yanit verilmesi zorunluluktur" ${ }^{109}$. Nitekim Danıştay da Anayasa Mahkemesi ve AİHM ile benzer görüştedir: “... kararın gerekçeli olması adil yargılanma hakkının ayrılmaz bir parçasıdır. Mahkemelerin kararlarında gerekçe gösterme zorunluluğunun kapsamı, kararın niteliğine göre değişebilir. Bununla birlikte ayrı ve açık bir cevap verilmesini gerektiren usul veya esasa dair iddiaların cevapsız bırakılmış olması, bir hak ihlâline neden

107 İNCEOĞLU, 2002, s. 309.

108 AYM, Mustafa Kahraman Başvurusu, T. 04.11.2014 Başvuru Numarası: 2014/2388, e.t.12.05.2018.

109 AYM, A.V. Başvurusu, T. 11.12.2014, Başvuru Numarası: 2013/216, RG. 12/5/2015 No: 29353; Aynı yönde, Düzgit Yalova Gemi İnşa Sanayi A.Ş. T.15.04.2015, Başvurusu Başvuru Numarası: 2013/8756, RG. 20.6.2015 No:29392, e.t. 12.05.2018, AYM Kararlar Bilgi Bankas1. 
olacaktır. Gerekçeli karar hakkının gereği olarak kararda tarafların esasa ve uyuşmazlığın çözümünde etkili olan iddialarının karşılanması zorunludur ${ }^{110}$ ".

AİHM, gerekçeli karar hükümlüye tebliğ edilmediği için, ilgili tarafından gerekçe göstermeden yapılan temyiz başvurusunun bu nedenle reddi halinde, sanığın gerçek ve etkili bir savunmadan mahrum bırakıldığı ve sonuç olarak 6'ncı maddenin 3'üncü fıkrasının b ve c bentleriyle bağlantılı olarak 1'inci fıkra hükmünün ihlal edildiği kanısındadır. Çünkü sanık kararının gerekçesini öğrenemediği için kanun yolu güvencesi işlevsiz hale gelmektedir. Bununla beraber, Komisyon, gerekçeli karar koşulunun mutlak olmayıp gerek davanın gerekse yargılama merciinin özelliği bakımından istisnalara maruz kalabileceğini belirtmektedir. Her bir yargılama sürecinde, karara karşı kullanılabilecek etkili bir kanun yolunun gerekleri dikkate alınmaktadır ${ }^{111}$. Anayasa Mahkemesi de gerekçeli kararın ilgiliye tebliğ edilmeden temyiz başvurusu yapmak zorunda bırakılmasını adil yargılama hakkının ihlali olarak kabul etmektedir ${ }^{12}$. Gerekçe öğrenilmeden kanun yollarına başvuru yapmak zorunda kalınması kişiye tanınan kanun yollarına etkili başvuru hakkını engellediği için adil yargılanma açısından önemlidir ${ }^{113}$. Bu nedenle AİHM, tarafların ilk derece mahkemesinin gerekçesini öğrenmeden temyiz için başvuru yapmak zorunda kalmasını sözleşmesinin 6'ncı maddesine aykırı

110 Danıştay, 13. Daire, E. 2017/936, K. 2017/1829, T. 06.06.2017, Kazancı Bilgi Bankası.

111 GÖLCÜKLÜ Feyyaz, “Avrupa İnsan Hakları Sözleşmesi’nde Adil Yargılanma”, AÜSBF Dergisi, cilt:49, Say1: 1-2, (s.199-223), s. 216.

112 Anayasa Mahkemesinin 20/3/2014 tarih ve Başvuru Numarası:2012/1034 sayılı kararına konu olayda, başvurucu iş mahkemesinde açtığı davada verilen kısa kararı süre tutum dilekçesi ile temyiz etmiş, Yargıtay, henüz ilk derece mahkemesinin gerekçeli kararı taraflara tebliğ edilmeden önce kararı onamışıtır. Mahkeme Yargıtay incelemesi sırasında gerekçeli karar hakkına uyumlu bir yargılama yapılmadığı ve gerekçeli karar hakkının ihlal edildiği sonucuna varmıştır:

"39'uncu Uygulamada, iş mahkemelerinde, 8 günlük temyiz süresi tefhim ile başladığından, bir kısım mahkemeler gerekçeli kararı taraflara tebliğ etmemekte, bir kısım mahkemeler ise gerekçeli kararı her halde taraflara tebliğ etmektedir. Bu durum somut başvuruda olduğu gibi bazı davalarda tarafların mahkemelerin gerekçesini bilmeden temyiz başvurusu yapmak zorunda kalmasına ve temyiz incelemesinde davanin taraflarının temyiz gerekçeleri bilinmeden inceleme yapllmasına neden olmaktadır. İlk derece mahkemesi kararının gerekçesini bilmeyen kişilerin temyiz hakkın gereği gibi kullandığ v ve tarafların temyiz nedenlerini bilmeyen temyiz merciinin de temyiz incelemesini sağlıkl bir şekilde yaptı̆̆ söylenemez. Bahsedilen şekilde yapılan temyiz başvurusu ve temyiz incelemesi, gerekçeli karar hakkı bağlamında adil yargılanma hakkına uygun olmayan bir yargılama yapılmasına sebebiyet vermektedir.e.t. 12.05.2018, AYM Kararlar Bilgi Bankas1.

${ }^{113}$ HARRIS D.J., Boyle M.O, Law of the European Convention on Human Rights to Administrative Law, London, Dublin, Edinburg, 1995, s. 376 Aktaran; INNCEOĞLU, 2002, s.310. 
görmektedir. Uygulamada, Ceza yargılaması ve Medeni yargılamada bazı istisnalar dışında henüz gerekçeli karar açıklanmadan hüküm sonucu taraflara tefhim edilmektedir. $\mathrm{Bu}$ durum kanun yollarına başvuru konusunda sorunların ortaya çıkmasına neden olmaktadır. Zira taraflar kararın gerekçesini bilmeden kanun yoluna başvurmak zorunda kalmaktadırlar ki bu da başvuru dilekçelerinin temelden yoksun olması sonucunu doğurmaktadır. Uygulamada bu konuda hak kaybına uğramamak adına süre tutum dilekçesi olarak adlandırılan fakat aslında hukukumuzda var olmayan bir dilekçe verilmektedir. Taraflar süre tutum dilekçesi vererek kanun yoluna başvurmuş sayılmakta daha sonra gerekçeli kararın tebliği ile ayrıntılı dilekçe verme haklarını saklı tutmaktadırlar. Özekes'e göre, asıl olan mahkeme kararlarının gerekçeleriyle birlikte tefhim ve tebliğ edilmesidir. Başka bir deyişle bir kararın tefhim ve tebliğ edilmesinden bahsedebilmek için kararın bütün unsurlarıyla açıklanmış olması gerekir. Asgari unsurları içermeyen karar, karar değil olsa olsa karar taslağı sayılmaktadır ve hâkim bu taslak üzerinde değişiklik yapma, değiştirme hakkına sahiptir ${ }^{114115}$. Dolayısıyla gerekçesi ile birlikte açıklanmamış karara karşı kanun yoluna başvurma süresinin başlamaması gerekir veya hüküm gerekçesi ile birlikte açıklanmalıdır ${ }^{116}$. Adalet Bakanlığı tarafindan yayınlanan İnsan Hakları Eylem Planında istinaf ve temyize başvuru süresinin hükmün tefhimi yerine gerekçeli kararın tebliğinden itibaren başlaması konusunda mevzuat çalışmaları yapılacağı belirtilmiştir ${ }^{117}$.

Gerekçesiz karar vermek, jürili yargılamada ihlale neden olmayabilmektedir. Bu konuyla ilgili Avusturya'ya ilişkin bir davada AİHM, bir ceza davasında yer alan jürinin mahkûmiyet kararında gerekçe gösterilmemesini, jüriye cevaplamaları için detaylı sorular sorulduğu için sözleşmeye aykırı bulmamıştır. Savunma bu sorulara itiraz etme

114 Özekes'e göre, kararın varlık kazandığı an ile kanun yoluna başvurulabilirlik kazandığı an arasında bir ayırım yapılması gerekmektedir. ÖZEKES Muhammet, Hukuk Yargılamasında Süre Tutum Müessesi Yoktur, Prof.Dr. Saim Üstündağ’a Armağan, Adalet Yayınevi, Ankara, http://ozekesseven.com/wpcontent/uploads/2020/01/18-Hukuk-Yarg\%C4\%B1lamas\%C4\%B1nda-S\%C3\%BCre-TutumM\%C3\%BCessesesi-Yoktur.pdf, Erişim:04.03.2021.

${ }^{115}$ Ancak Yargıtay, tefhim edilen kısa karara uygun gerekçeli karar yazılması gerekirken bu kurala aykırı şekilde gerekçeli karar yazılmasının hukuka aykırı olduğuna karar vermiştir. Yargıtay, 14.Hukuk Dairesi, E.2018/1827, K.2018/1948, T.15.05.2018, Kazanc1 Bilgi Bankası.

${ }^{116}$ Aynı yönde görüş için POSTACIOĞLU ilhan, Medeni Usul Hukuku Dersleri, Sulhi Garan Matbaası, İstanbul, 1975, s.710-711.

117 İnsan hakları Eylem Planı, 2021, s. 43. 
ve değiştirilmesini isteme hakkına sahiptir; ayrıca hukukun yargıç tarafından jüriye yanlış anlatılması da kararın iptali için bir neden oluşturabilmektedir ${ }^{118}$. AİHM, başka bir kararında $^{119}$, jürili sistemlerde verilen kararın gerekçesiz olmasının adil yargılanma hakkını ihlal etmeyeceğini belirtmiş ancak “...adil bir davanın gerekliliklerinin yerine getirilmesi için, sanı ve halkın verilen kararı anlayabilmesini sağlayacak yeterli güvencelerin olmasl gerekmektedir. Bu usul güvenceleri, örneğin jüri üyelerine, sunulan delillerle veya hukukî sorunlarla ilgili talimatlar vermek ya da açıklamalar yapmak veya hâkim tarafından belirli ve muğlâk olmayan ve kararın yapısını oluşturmaya ya da jürinin cevaplarındaki gerekçe eksikliğini telafi etmeye yönelik sorular sormaktan ibaret olabilir" ifadelerini kullanarak jürili sistemde gerekçesiz karar verebilme yetkisinin sınırını çizmiştir.

Mahkemeler, taraflarca kendilerine yöneltilen bütün delilleri, karar bakımından önemli olsun olmasın ön yargısız bir şekilde değerlendirmek durumundadır. AİHM, Van de Hurk kararında ${ }^{120}$ mahkemelerin, kendilerine sunulan her iddiaya ayrıntılı bir cevap verilmesini gerektirmese dahi 6'ncı maddenin ilk fikrasının yargı organlarına davayla yakından ilişkisi bulunan ve davanın temeli ile ilgili olan konularda sorulan sorulara cevap vermeleri yükümlülüğü yüklediği sonucuna varmıştır. Başvurucunun mahkemeye belirli ve süratli cevap gerektiren bir mütalaa sunduğu Hiro Balani davasında ${ }^{121}$ mahkeme talebi cevaplandırmamıştır. Bu durumun, mahkemenin meseleyi ele almayı ihmal mi ettiği yoksa talebi reddetmeyi mi düşündügü; eğer böyleyse reddetme nedenlerinin ne olduğu hususlarını anlamayı imkânsız hale getirdiği gerekçeleriyle, 6'ncı maddenin ihlal edildiği AİHM tarafından belirtilmiştir. Hadjianastassiou ${ }^{122}$ kararında ise sözleşmeci devletlerin yargı örgütlerini 6'ncı maddenin gereklerine uydurmak hususunda geniş bir takdir yetkisine sahip bulunduğu belirtildikten sonra mahkemelerin, kararlarını mutlaka yeterli açıklıkta gerekçelendirmekle yükümlü olduğu belirtilmiştir. 6'ncı maddenin 1'inci

\footnotetext{
118 İNCEOĞLU, 2002, s. 311.

119 AİHM, Taxquet Karar1, T.16.11. 2010, 926/05, hudoc.echr.coe.int e.t.2.05.2018, § 93.

120 AİHM, Van de Hurk/ İspanya Kararı, T.18.04- 02.05 1994, hudoc.echr.coe.int e.t. 12.05.2018 $§$ 63-64.

121 AİHM, Hiro Balani/İspanya Karar1, T.9.11.1994, hudoc.echr.coe.int e.t. 12.05.2018, §28.

122 AİHM, Hadjianastassiou/Yunanistan Kararı, T. 16.12.1992, hudoc.echr.coe.int e.t. 12.05.2018, §22-23.
} 
fikrasının mahkemelere, kararlarında gerekçe gösterme zorunluluğu getirdiği Higgins ve diğerleri, kararında da tekrar edilmiştir ${ }^{123}$.

Şüphesiz, AİHS'nin 6'ncı maddesine uygun bir gerekçeden söz edebilmek için, somut davada uygulanabilir geçerli bir mevzuat hükmüne dayanılması gerekmektedir. Nitekim AİHM, başvuranın baroya kayıt talebinin reddedilmesine ilişskin gerekçenin davada uygulanabilir olan kanun düzenlemesindeki nedenlerden birine dayanmamasını adil yargılanma hakkının ihlali olarak görmüştür ${ }^{124}$.

Bir yargı kararının gerekçesiz olması adil yargılanma hakkının ihlalini oluşturacağı gibi, yetersiz bir gerekçe de aynı sonucu doğurabilecektir. H./Belçika kararında, AİHM, barodaki kaydı daha önce silinmiş olan başvuranın tekrar kayıt talebinin, mevzuatta yer alan” istisnai koşullar” in bulunmadığı gerekçesiyle reddedilmesini gerekçeli karar hakkına aykırı bulmuştur. AİHM'ne göre, söz konusu “istisnai koşullar” düzenlemesi ve konuya ilişkin önceki içtihatlar belirsizdir. Bu durum, yeterli gerekçelendirmeyi daha gerekli kılmaktayken ret kararında başvurucunun koşullarının neden istisnai olmadığ açıklığa kavuşturulmamıştır. Benzer bir durumu AİHM Georgiadis/Yunanistan kararında değerlendirmiştir. Başvuranın, haksız tutuklama nedeniyle tazminat talebinin mevzuattaki" büyük ihmal" kavramına istinaden reddedilmesini adil yargılanma hakkının ihlali olarak görmüştür. Bu olayda da "büyük ihmal" düzenlemesinin net olmaması nedeniyle mahkemelerin daha detaylı gerekçeler vermesi gerektiğini ifade etmiş; başvuranın kendi kanıtlarını ileri sürme imkânına sahip olmamasının AİHS’nin 6'ncı maddesinin 2. fikrasının ihlali olduğuna karar vermiştir ${ }^{125}$.

Anayasa Mahkemesi, Anayasa'nın 36'ncı maddesi uyarınca inceleme yaptığ birçok kararında, ilgili hükmü Sözleşme'nin 6'nc1 maddesi ve AİHM içtihadı 1şı̆̆ında yorumlamak suretiyle, gerek Sözleşme’nin lafzi içeriğinde yer alan gerekse AİHM

\footnotetext{
123 TURAN, Hüseyin, “Adil Yargılanma Hakkının Bir Unsuru Olarak Mahkeme Kararlarında Gerekçe”, Yargıtay Dergisi, Cilt: 31, Say1:3, (s. 107-11)1, s. 108.

124 AİHM De Moor/Belçika, T. 23 06.1994, § 51-57, hudoc.echr.coe.int e.t. 12.05.2018, §53.

125 BEKRİ, 2014, s. 211.
} 
içtihadıyla adil yargılanma hakkının koruma alanına dâhil edilen ilke ve hakları, Anayasa'nın 36'ncı maddesi kapsamında kabul etmiştir ${ }^{126}$.

Yargı kararlarının gerekçesi, hâkimin takdir hakkını kullanırken gözettiği hususları detaylı bir şekilde açıkladığı alandır. Bu durumda yukarıda da belirtildiği üzere keyfiliği önler. Ancak, bir kararın gerekçeli olup olmadığının veya belirtilen gerekçelerin yeterliliğinin üst yargı mercilerince incelenmesi son derece mühimdir. Gerek AYM gerekse AİHM bu konuda oldukça hassas davranmakta ve gerekçeli karar konusunda detaylı inceleme yapmaktadırlar. Ancak belirtmek gerekir ki bu çalışma hazırlanırken AYM kararlarının taranması sırasında mahkemenin yargı kararlarının gerekçeli olmasının önemi konusunda verdiği kararlardaki gerekçeleri aynı paragrafları içerdiği görülmüştür. Kararlardaki atıf yapılan AYM ve AİHM kararları dahi aynıdır. Oysaki her uyuşmazlık kendine özgüdür ve özgün bir gerekçeyi hak etmektedir.

\section{SONUÇ}

Mahkeme kararlarının gerekçeli olması sorununa yaklaşmanın birkaç yolu vardır. Gerekçe zorunluluğu ilk etapta yargılamanın sonlandırılması için usuli bir kural olarak görünmektedir. Tarafları hâkimin hata ve keyfiliğine karşı korumanın yanı sıra kanun yollarında kararın değerlendirilmesini de kolaylaştıran bir araç olarak karşımıza çıkmaktadır. Bu açıdan bakıldığında hem taraflar hem de hâkime tanınan bir hak ve ayrıcalıktır. Ancak aynı zamanda hukuk yaratılmasında ve hukukun üstünlüğünün yerleşmesinde önemli rol oynar. Hâkim pozitif bir hukuk kuralını veya evrensel hukuk ilkesini yorumlayıp kararına dayanak yaptığında bu gerekçeye yansır. Bir hukukî ilkenin hâkim tarafından yorumlanması ise hukuk yaratma örneğidir.

Mahkeme kararlarının gerekçeli olması gerekliliği ulusal ve uluslararası belgelerde ifade edilmiştir. AİHM bir yandan kararların gerekçeli olmaması veya var olan gerekçenin tatmin edici olmaması konusunu adil yargılanma hakkının ihlali olarak görürken diğer yandan AİHS'nin 45. maddesine göre kendi kararlarını gerekçeli

126 AYM, Türkan BAL Başvurusu, T. 06.01.2015, Başvuru No: 2013/ 6932, Tarih: 06.01.2015, RG. 09.05.2015 No:29350, e.t. 12.05.2018, AYM Kararlar Bilgi Bankası. 
yazmalıdır. $\mathrm{Bu}$ gerekçe çoğu zaman olayın geniş özeti, uyuşmazlığa uygulanacak hukukun belirlenmesi ve varılan sonuçtan ibarettir. Aynı durum Anayasa Mahkemesi için de geçerlidir. Çalışmamızda belirttiğimiz üzere yargı organının kararlarını gerekçeli vermesi anayasal bir zorunluluktur. Anayasa Mahkemesi yargı kararlarını bu açıdan denetlerken diğer yandan kendi kararlarını gerekçeli vermelidir. Türk yargı organlarında gerekçeli karar ile ilgili tespit ettiğimiz en önemli sorun, benzer konularda verilen kararlarda aynı paragraf ve aynı tanımların işlenmesidir. Halbuki hukukta her somut olayın açıklanmaya ve aydınlatılmaya ihtiyaç duyan bir tarafı bulunmaktadır. Özellikle yüksek yargı organlarının görevlerinden biri de uyuşmazlığa uygulanacak evrensel ilkelerin belirlenmesi ve gerekirse yeni ilkeler yaratmaktır. Gerekçe bu konuda yarg1 organının "dili” görevi görmektedir. Ancak iş yükünün çok olması, personel sayısının yetersizliği gibi nedenlerle kararların gerekçesi konusunda yeteri özeni gösteremeyen yarg1 organına karşı kanun koyucu gerekçeyi bazen bir "firsat" olarak önüne koymaktadır. Çalışmamızda zikrettiğimiz IYYUK 27'nci madde de belirtilen yürütmenin durdurulması kararlarını reddederken gerekçe gösterme zorunluluğunun olmaması buna örnektir. Bu konuda atılmış sevindirici bir adım İnsan Hakları Eylem planında yer almaktadır. Buna göre, hâkim ve savcıların terfi sistemlerinin yeniden yapılandırılmasında kararları yeterli gerekçeyle yazıp yazmadıkları da kriter olarak değerlendirilecektir ${ }^{127}$.

Yargı kararını, hukukî gerekçeye dayanan irade açıklamaları olarak tanımlamak sanıyoruz ki yanlış olmayacaktır. Uyuşmazlık hakkında, tarafların taleplerine karşı, ancak mahkemenin ortaya koyacağı karar bir cevap olacak ve uyuşmazlığı ortadan kaldıracaktır. Bu sebeple yargı kararları şüphesiz saygı duyulması, uyulması, yerine getirilmesi gereken, belki de insan tarafından verilip en az sorgulanan irade açıklamalarıdır. Ancak, buna rağmen deyim yerindeyse "hikmetinden sual olunmayan" kutsanmış nitelikte değillerdir. Bu sebeple, kararın ancak gerekçesiyle birlikte, tatmin edici, uyuşmazlığı sona erdirici ve tarafları ikna edici nitelik kazanması mümkündür. Hukuka en uygun karar dahi, gerekçeye dayanmadıkça ikna edici olmayacak, tereddütleri içinde taşıyacaktır.

127 İnsan Hakları Eylem Planı, s.31 
Gerekçe, hukukun gelişmesinde, nitelikli hukukçu yetiştirilmesinde, yargının bağımsız ve tarafsızlığının dışa yansımasında, bireyin ve toplumun adalet duygusunun tatmininde, başvuru yollarının ve savunma hakkının etkin kullanılmasında, yargılamada aklın ve vicdanın egemen kılınmasında çeşitli fonksiyonları olan önemli bir araçtır. Hâkimleri, kararının nedenlerini, hukukî dayanaklarını açıklamaya zorladığı ve uyuşmazlığın taraflarını ikna etme amacını taşıdığı için keyfiliğe karşı bir siperdir. Hâkim gerekçede taraflara yol göstermelidir. Özellikle idarî yargılama düzeninde gerekçenin idarenin önlem almasını sağlamaya aracılık ettiğinden bahsedebiliriz. Böylece idareyi hukuka uygun davranmaya zorlayacak, uzun vadede yargının iş yükü de azalabilecektir.

Yargı kararlarının gerekçeleri, yalnız ulusal değil, uluslararası yargı yerlerinin de denetimi altındadır. $\mathrm{Bu}$ nedenle yargı mercilerinin prestijlerinin artması açısından, hâkimler gerekçeli kararlarını verirken insan hakları ekseninden bakmalıdırlar. $\mathrm{Bu}$ durum, mahkemelere güveni arttıracak, yargı kararlarının denetimini kolaylaştıracak, adil yargılanma ilkesinin ülkemizde yerleşmesinde katkıda bulunacaktır.

\section{KAYNAKÇA}

AKIN, İbrahim, Yargı Kararlarında Gerekçe (Bilgi Teorisi ve Mantık Açısından Değerlendirme), Kazancı Bilgi Bankası, Ankara, 2001.

ALP, Mustafa, "Anayasa Hukuku Açısından Mahkeme Kararlarında Sözde (Görünürde) Gerekçe”, Prof. Dr. Mahmut Tevfik Birsel'e Armağan, İzmir; Dokuz Eylül Üniversitesi Yayın1, s. 425-441.

ARAL Vecdi, Hukuk ve Hukuk Bilimi Üzerine, 7. Basım, On iki Levha Yayınları, İstanbul, 2012.

AŞÇIOĞLU Çetin, "Yargı Kararlarında Gerekçe", Ticaret Hukuku ve Yargıtay Kararları Sempozyumu IX, s.43-49.

AŞÇIOĞLU, Çetin, "Yargıda Gerekçe Sorunu”, Hukuk Felsefesi ve Sosyolojisi Arkivi (8'inci Kitap), İstanbul Barosu Yayınları, İstanbul, y1l:2003, s.154-161. 
ATALI, Murat, Pekcanıtez Usul Medeni Usul Hukuku, 15'inci Bas1, XII Levha Yayınları, İstanbul, 2017, C. III.

ATALI, Murat / ERMENEK, İbrahim, Medeni Usul Hukuku, Seçkin Kitabevi, Ankara, 2019.

ATAY, Ethem, "Yargı Kararlarının Gerekçelendirilmesi ve İdari Yargıdaki Uygulama Alanı", Danıştay Dergisi, Yı1:2018, Sayı:147, (s. 7-32).

BEKRİ, M. Nedim, “Gerekçeli Karar Hakkı”, Ankara Barosu Dergisi, Cilt: 72, Sayı:3, (s. 205-228).

BLANCO, Florent, Contentieux Administratif, 1. Edition, Themis Droit Puf, Paris, 2019.

BROYELlE, Camille, Contentieux Administratif, 7. Edition, L.G.D.J., Paris, 2019.

CANDAN, Turgut, Açıklamalı İdari Yargılama Usul Kanunu, 2. Baskı, Maliye ve Hukuk Yayınları, Ankara, 2006.

CASTAING-ZENATI, Frédéric, "La motivation des décisions de justice et les sources du droit”, Recueil Dalloz, 2007.

CENTEL, Nur, "İnsan Hakları Avrupa Mahkemesi Kararları Işı̆̆ında Tutuklama Hukukuna Eleştirel Yaklaşım”, MÜHF-HAD, Cilt:17, Sayı:1-2, (s.49-93).

CHAPUS, Droit du Contentieux Administratif, 8. Edition, Montchrestien, Paris, 1999.

COHEN, Matilda, "Reason Giving in Court Practice: Decision - Makers At The Crossroads", Colombia Journal of European Law, Y11:2008, Vol:14, No:2, (p.257-276).

DEMİR, Mehmet, Hâkimin Takdir Hakkı, Yayımlanmamış Yüksek Lisans Tezi, Ankara Üniversitesi Sosyal Bilimler Enstitüsü, 1994.

DEMİRCIOĞLU, Yaşar, Medeni Usul Hukukunda insan Hakları ve Adil Yargılanma Güvenceleri, Yetkin Yayınevi, Ankara, 2007.

ERCAN, İsmail, Medeni Usul Hukuku, Yetkin kitabevi, Ankara, 2020. 
GÖLCÜKLÜ Feyyaz, “Avrupa İnsan Hakları Sözleşmesi’nde Adil Yargılanma”, AÜSBF Dergisi, Cilt:49, Say1: 1-2, (s.199-223).

GÖZÜBÜYÜK, Şeref, Yönetsel Yargı, 24.Baskı, Turhan Kitabevi, Ankara, 2011.

GÖZÜBÜYÜK Şeref/TAN Turgut, İdare Hukuku C.II, Turhan Kitapevi, Ankara, 2012.

GÜRSOY, Mustafa, "Yürütmenin Durdurulması Kararında Gerekçesizlik Sorunu”, Terazi Hukuk Dergisi, Y11:2007, Say1: 14, (s. 61-66).

HİRŞ, Ernst, Pratik Hukukta Metot, 8. Bask1, BTHAE Yayınlar1, Ankara, Y11:2017, - Bu kitabın ilk baskısı 1944 tarihinde yapılmıştır.

İNCEOĞLU, Sibel, İnsan Hakları Avrupa Mahkemesi Kararlarında Adil Yargılanma Hakkı, Beta Yayınları, İstanbul, 2002.

İnsan Hakları Eylem Plan1, 2021, https://rayp.adalet.gov.tr/resimler/1/dosya/insan-haklariep02-03-202115-14.pdf

KARAKOÇ, Yusuf, "Yargı Kararlarının Dili ve Gerekçesi”, HFSA 16. Kitap, İstanbul Barosu Yayınları, İstanbul, Y11: 2007, (s. 275-283).

KARAYALÇIN, Yaşar, Hukukta Öğretim-Kaynaklar-Metot-Problem Çözme, 4.Basım, BTHAE Yayınları, Ankara, 1994, (s. 116-117)- Bu kitabın ilk baskısı 1977 tarihinde yapılmıştır.

KUNTER, Nurullah, Ceza Muhakemesi Hukuku, Yaylac1lık Matbaası, İstanbul,1989.

KUNTER Nurullah, YENISEY Feridun, Muhakeme Hukuku Dalı Olarak Ceza Muhakemesi Hukuku, Arıkan yayınevi, İstanbul, 2016.

KURU, Baki, Hukuk Muhakemeleri Usulü, 6. Bask1, C.3, Demir- Demir Yayınevi, İstanbul, 2001.

ÖKÇESIZ, Hayrettin, "Devlet ve Gerekçesi”, Hukuk Felsefesi ve Sosyolojisi Arkivi (HFSA) 10, İstanbul Barosu Yayını, (s. 11-13).

ÖZEKES, Muhammet, "Medeni Usul Hukukumuzda Yok Hüküm ve Etkisiz Hüküm”, Yargitay Dergisi, Y11:Ekim 2000, Cilt: 26, Say1: 4, (s.661-699). 
ÖZEKES, Muhammet, Medeni Usul Hukukunda Hukukî Dinlenilme Hakkı, Yetkin Yayınları, Ankara, 2003.

ÖZEKES, Muhammet, "İhtiyati Haciz Kararlarının Gerekçeli Olması ve Kanun Yoluna Başvuru”, Prof. Dr. Yavuz Alagonya İçin Armağan, Yı1: 2007, (s 469-484).

ÖZEKES Muhammet, "Hukuk Yargılamasında Süre Tutum Müessesi Yoktur”, Prof.Dr. Saim Üstündă̆’a Armağan, Adalet Yayınevi, Ankara, 2009, http://ozekesseven.com/wpcontent/uploads/2020/01/18-Hukuk-Yarg\%C4\%B1lamas\%C4\%B1nda-S\%C3\%BCre-TutumM\%C3\%BCessesesi-Yoktur.pdf

ÖZTÜRK, Burak, Fransız ve Türk Hukukunda İdarenin Düzenleme Yetkisinin Kapsamı, Yetkin Yayınları, Ankara, 2009.

ÖZYÖRÜK, Mukbil, Tercüman Gazetesi, 07 Aralık 1979 tarihli köşe yazısı.

PEKCANITEZ, Hakan, Pekcanıtez Uusul Medeni Usul Hukuku, Oniki Levha Kitabevi, İstanbul, 2017.

PONTHOREAU, Marie Claire, "Réflexions sur la motivation des décisions juridictionnelles en droit administratif français”, R.D.P.,Y11:1994, (s.747-765).

POSTACIOĞLU ilhan, Medeni Usul Hukuku Dersleri, Sulhi Garan Matbaası, İstanbul, 1975.

SHUMAN, Samuel, "Justification of judicial decisions", California Law Review, Y1l: 1971, Vol: 59, No: 3, A Tribute to Hans Kelsen, (pp. 715- 732).

SUNAY, Zuhal Aysun, İptal Davalarında Gerekçeli Karar Hakkı, Seçkin Yayınevi, Ankara, 2016.

ŞAHIN, Cumhur/GÖKTÜRK, Neslihan, Ceza Muhakemesi Hukuku II, Seçkin Yayınevi, 2016.

ŞEKER, Hilmi, "Strazburg Yargı Kararlarında Doğru, Haklı, Yasal ve Makul Gerekçe Biçimleri”, Ankara Barosu Dergisi, Y11: 2007, Cilt: 2. 
ŞEKER, Hilmi, Esbabı Mucibeden Retoriğe Hukukta Gerekçe, Beta Yayınları, İstanbul, 2010.

ŞEN, Ersan / ÖZDEMIR Bilgehan, "Tutuklama Uygulamalarına Bir Bakış: Tutuklamada Gerekçesizlik Sorunu”, İstanbul Barosu Dergisi, Cilt:87, Sayı:1, (s. 15- 24).

ŞENTUNA, Mustafa Tarık, 5271 Sayılı Ceza Muhakemesi Kanunu'nda Tutuklama ve Adli Kontrol, Adalet Yayınları, Genişletilmiş 2. Bası, Ankara 2007.

TURAN, Hüseyin, “Adil Yargılanma Hakkının Bir Unsuru Olarak Mahkeme Kararlarında Gerekçe", Yargıtay Dergisi, Cilt: 31, Sayı:3, (s. 107-111).

TUTUMLU, Mehmet Akif, Hukuk Yargılamasında Hüküm ve Gerekçeli Karar, Seçkin Yayınevi, Ankara.

TÜRKMEN, Ali, “Türk Yargı Kararlarında Gerekçe ve Önemi”, Legal Hukuk Dergisi, Cilt:13, Say1:154, (s. 39-60).

UZUN, Ertuğrul, "Yargıtay Kararlarından Örneklerle Yargı Kararlarında Gerekçelendirme Zaafiyeti”, Legal Medeni Usul ve İcra İflas Hukuku Dergisi, Y11:2007, Say1: 2.

YAVAŞ, Murat, "Medeni Yargılamanın Amacı Bağlamında İspat Yükü Kavramı", Mehmet Akif AYDIN'a Armağan, Marmara Üniversitesi Hukuk Fakültesi Dergisi, Y11:2015, (s.741-761).

YENİSEY, Feridun, “Tutuklama Kararında Gerekçe Sorunu”, Kazancı Hakemli Hukuk Dergisi, Y11:2009, Say1: 53, (s. 174- 185).

YERDELEN, Erdal, Ceza Muhakemesinde Hükmün Gerekçesi, Adalet Yayınevi, Ankara, 2015.

YILMAZ, Ejder, Hukuk Sözlüğü, Yetkin Yayınları, Ankara, 2006.

YÜCE, Turhan Tufan, Ceza Muhakemesi Hukukunda Hukuk Devleti Esasları, Atatürk Üniversitesi Basımevi, Erzurum, 1968.

YÜCEL, Mustafa Tören, "Kararlarda Gerekçe ve Muhalefet Şerhi”, HFSA (8. Kitap), İstanbul Barosu Yayın1, yı1:2003, (s. 162-170). 